\title{
Universities and open innovation: the determinants of network centrality
}

\author{
Robert Huggins ${ }^{1} \cdot$ Daniel Prokop $^{1} \cdot$ Piers Thompson $^{2}$ \\ Published online: 15 March 2019 \\ (c) The Author(s) 2019
}

\begin{abstract}
This paper addresses the 'network' and 'open innovation' paradigms by seeking to examine the factors associated with structural positioning within university-industry networks. Drawing upon a network analysis of knowledge-based ties held by universities across the regions of the UK, it is found that those universities with the most central positions (network centrality) within university-industry network structures also have high rates of relational involvement in activities such as spin-off generation and engagement in externally funded research projects. Some forms of activity, in particular intellectual property protection through patenting, are found to be negatively associated with centrality. Spatial location is largely found to be unrelated to the network centrality of universities. By utilising network centrality as one measure of the open innovation capability of universities, the paper indicates that a range of institutional characteristics and factors tend to either promote or limit the engagement of universities in open innovation practices.
\end{abstract}

Keywords Universities · University-industry links · Open innovation · Network centrality · Regions

JEL Classification: $\mathrm{I} 23 \cdot \mathrm{O} 31 \cdot \mathrm{O} 32 \cdot \mathrm{O} 33 \cdot \mathrm{O} 34$

\section{Introduction}

The emergence of the network paradigm has led to a growing interest and recognition in understanding the influence of network structures upon innovation (Bergman 2009; Ter Wal and Boschma 2009; Broekel and Hartog 2013; Boschma et al. 2014; Andrade Rojas

Robert Huggins

hugginsr@cardiff.ac.uk

Daniel Prokop

prokopd@cardiff.ac.uk

Piers Thompson

piers.thompson@ntu.ac.uk

1 School of Geography and Planning, Cardiff University, Cardiff, UK

2 Nottingham Business School, Nottingham Trent University, Nottingham, UK 
et al. 2018; De Noni et al. 2018; Liang and Liu 2018; Szücs 2018), in particular the network structures pertaining to knowledge flows and patterns of innovation (Glückler 2007; Huber 2012a, b; Sebestyén and Varga 2013; Bogers et al. 2017; Roper and Love 2018). Research on the performance of organisations, such as firms and universities, has made significant advances through studies that analyse the networks within which these organisations are embedded. Specifically, it has been argued that the network space occupied by actors, defined by the nature of the relationships, interactions and ties, may be equally, if not more, important than the geographic space within which actors are located and interact (Huggins et al. 2012a).

The term 'open innovation' has been coined to define the networked nature of innovation mechanisms. According to Chesbrough (2003, p. xxiv) open innovation is 'a paradigm that assumes that firms can and should use external ideas as well as internal ideas ... as the firms look to advance their technology'. Open innovation theory has begun to provide important insights into the heightened role of knowledge accessing and networks in facilitating innovation and spurring the openness of innovation processes (Chesbrough 2003, 2011; Chesbrough et al. 2006; Laursen and Salter 2006; Gassmann 2006; Dahlander and Gann 2010; Bogers et al. 2017; Stanko et al. 2017 Bogers et al. 2018; Santoro et al. 2018). More recent definitions, such Chesbrough and Bogers (2014), increasingly stress that open innovation's key feature is the organisation's ability to manage these knowledge flows.

From the perspective of universities, open innovation is closely related to their role as entrepreneurial agents, particularly that concerned with their knowledge transfer and commercialisation capabilities (Sharifi et al. 2014). With this remit of entrepreneurial agency, universities are increasingly portrayed as core knowledge-producing entities that can play an enhanced role in driving innovation and economic development processes by providing knowledge for industry (Fritsch 2002; Huggins et al. 2008). Similar to the open innovation paradigm, the emergence of the entrepreneurial university concept is a recognition that rather than a focus on the internal knowledge possessed or generated by firms, knowledge sourced from universities is considered to be a key factor within modern open innovation processes (Lawton Smith and Bagchi-Sen 2006; Rosli and Rossi 2016).

The aim of this paper is to explore the role of universities as 'open innovators' in terms of the extent to which they hold prominent positions within particular network architectures, bridging and brokering connections between other actors, and being strategically positioned at the centre of these architectures (Burt 2005; Jonsson et al. 2015). Therefore, the objective of the paper is to argue that the concept of open innovation should be increasingly integrated into frameworks examining the role of universities as entrepreneurial actors (Lawton Smith et al. 2014). In particular, it suggests that network positioning and centrality is one lens for considering such open innovation capability. Fundamentally, the argument is that universities with high rates of network centrality can be considered as the type of open innovators that sustain significant levels of relational involvement with external actors through interactions that promote knowledge exchange. This approach begins to give consideration as to how the overall structure of open innovation networks and practices are formed, especially from the perspective of universities. Such an analysis provides insights to universities in terms of their relative position within these networks as well as policymakers with a remit to increase university-industry engagement. From a theoretical perspective, it connects the literature on open innovation with a parallel stream of research concerning network analysis.

In network analysis terms, positioning is closely associated with concepts and techniques that identify the centrality of actors within particular network systems, with such centrality defined as the importance or prominence of an individual actor in a given 
network (Freeman 1977, 1979; Borgatti 2005; Everett and Borgatti 2005; Owen-Smith and Powell 2004). Within the field of innovation studies, those actors with high centrality can be considered to be the most 'open innovators' within innovation or knowledge network systems (Fleming and Waguespack 2007). In this sense, the structural position of actors within these network systems is an important indicator of their open innovation capacity and capability (Belussi et al. 2010; Cassi and Plunket 2013).

The dynamics of open innovation practices suggests that there are potentially spatial dimensions to these network systems. For example, successful connectivity in global spaces is often considered to be the outcome of an initial system of localised interaction, whereby it is the knowledge crossing hallways and streets that initially catalyses intellectual exchange and knowledge transfer across oceans and continents (Glaeser et al. 1992). This phased transition is necessitated by the risk that organisations become rigid and outdated when local networks fail to keep abreast of knowledge emerging outside of their respective region (Camagni 1991; Izushi 1997; Bathelt et al. 2004; de Noronha Vaz and Nijkamp 2009; Ter Wal and Boschma 2011; Carayannis and Meissner 2017; Trippl et al. 2017). However, not all firms or universities may participate in networks at multiple spatial levels. Whereas organisations-including universities-with less resources and lower absorptive capacity may tend to continue to network mainly locally, those with greater resources and higher absorptive capacity are likely to be more connected to inter-regional networks (Cohen and Levinthal 1990; Drejer and Lund Vinding 2007; Van Geenhuizen 2008; Huggins and Johnston 2009; Fantino et al. 2015; D'Ambrosio et al. 2017; Johnston and Huggins 2017). This has led some to question the view that knowledge transfer is confined to local milieus, arguing that firms source knowledge from selected providers located outside the local milieu by investing in the building of new channels of communication (Bathelt and Glückler, 2003; Wolfe and Gertler 2004; Fontes 2005; Gertler and Levitte 2005; Fitjar and Rodriguez-Pose 2011; Qiu et al. 2017).

With the above in mind, this paper seeks to better understand if, and why, some universities are more networked and engaged in open innovation processes than others. In particular, it seeks to address the following key questions: (1) to what extent do universities differ in terms of their open innovation capacity and capability, as measured by their position and centrality in networks between university and industry?; (2) what factors are most associated with the centrality of universities in these networks; and (3) to what extent do these factors vary when considering networks over different levels of spatial reach? The methods employed for the empirical part of the paper consists of social network analysis followed by regression analysis. These analyses are based upon data indicating the links between universities and firms and other organisations within and across the regions of the UK, drawing upon a network analysis of almost 10,000 knowledge-based ties held by universities.

The remainder of the paper is structured as follows. Section 2 examines some of the key literature relating to the concepts of network structure, open innovation and spatiality, particularly in the context of universities. Section 2 further focuses on issues related to the flow of knowledge in terms of the spatiality of open innovation. Section 3 presents the methods underlying the collection and analysis of the network data, as well as the methods concerning the regression analysis that seeks to explain the determinants of the network centrality of a university. Section 4 presents the results of the network analysis and the key features of these networks at a regional level, whilst Sect. 5 presents the results of the regression modelling. The concluding Sect. 6, seeks to interpret the key findings emerging from the analysis and to reflect on how the structure, spatiality and strength of knowledge 
network ties should be integrated into future analyses relating to the role of universities as increasingly important agents of entrepreneurship and innovation.

\section{Universities, network structure, and the spatiality of open innovation}

The aim of this section is to critique a range of literature stemming from the fields of network analysis, innovation and entrepreneurship studies, and regional economic geography as a means of proposing a conceptual framework for understanding why some universities are better 'positioned' within networks that facilitate open innovation. In general, the framework proposed consists of the following three overarching propositions. First, innovation outcomes for organisations are likely to be at least partly determined by their position within particular network structures of actors through which knowledge flows. Second, the position of universities within networks facilitating knowledge flow and innovation through engagement with industrial actors is likely to be associated with previous relational involvement, i.e. the pre-existing links of these universities with a range of other actors and activities. Third, it is proposed that different forms of relational involvement will be associated with different forms of networks in terms of the spatial reach of actors.

\subsection{Network structure and space}

The network space of actors can be usefully analysed by studying their position within a particular network structure through the use of social network analysis techniques (Cantner and Graf 2006; Bergman and Maier 2009; de Socio 2010). Social network analysis, as developed by sociologists, maintains a key behavioural assumption that any actor typically participates in a network system involving other actors that are significant reference points in decision-making processes (Knoke and Kuklinski 1982). The nature of the relationships a given actor has with other system members may, therefore, affect the focal actor's actions. Social network analysis has been increasingly applied to examinations of the flow of knowledge across organisations and the knowledge networks these organisations utilise to facilitate innovation (Sorenson et al. 2006; Fleming et al. 2007; Schilling and Phelps 2007; Varga and Parag 2009; Zaheer et al. 2010; Leon et al. 2017; Andrade Rojas et al. 2018; Park et al. 2018).

There is a growing school of research focused on analysing the impact of knowledge network structures on innovation outcomes (Powell et al. 1996; Ahuja 2000; Bonaccorsi and Giuri 2001; Knoben et al. 2006; Knoben and Oerlemans, 2012; Schilling and Phelps 2007; Whittington et al. 2009; Dong et al. 2017; Lyu et al. 2017; Sun and Cao 2018). Research has drawn on network structure conceptions such as 'small worlds', whereby dense clusters of network actors are linked to other clusters via a relatively small number of bridging links (Watts 1999; Gulati et al. 2012). Similarly, research drawing on Burt's $(1982,1992,2005)$ notion of structural holes, whereby actors who link previously unconnected actors within a network are considered to occupy privileged and central positions, has been applied to innovation studies (Stuart 1998; Ahuja 2000; Zaheer and Bell 2005; Massard and Mehier 2009; Zaheer and Soda 2009; Tortoriello 2015; Tang et al. 2017; Kim et al. 2018; Zang 2018). These studies all tend to identify network actor centrality as being 
associated with innovation outcomes, as well as the extent to which actors are embedded within either closed or open network structures.

The seminal study by Powell et al. (1996) on network structure and innovation in the biotechnology sector found that the nature of previous ties and relational involvement were an indicator of centrality and positional strength in these networks. Similarly, Burt (1992) argues that structural holes in the form of the connection gaps within networks are an indication of the social structure of competition, suggesting that such competition is itself a matter of the relations existing between actors, rather than the 'physical' attributes of actors (Burt 1992). Interestingly, Burt (2005) has sought to connect the concept of structural holes to Schumpeterian notions of innovation, suggesting that those actors in a position to span networks are the 'network entrepreneurs' driving growth and development. Unsurprisingly, therefore, network structure concepts have increasingly permeated the work of those scholars studying innovation networks (Vonortas 2009; Tortoriello 2015; Kim et al. 2018). However, there are few studies that have applied the concept in an empirical manner with regard to examining links between universities and industry.

\subsection{Universities and relational involvement}

There has been an increasing interest in the role of universities and other public research institutes in knowledge transfer, described as the 'third mission' (Etzkowitz et al. 2000; Gulbrandsen and Slipersæter 2007; Benneworth et al. 2015; Cesaroni and Piccaluga 2016; Mejlgaard and Ryan 2017; Di Nauta et al. 2018). These knowledge transfer activities of universities can be extremely diverse ranging from engagement activities such as collaborative research, contract research, consultancy through to commercialisation activities associated with patenting and academic entrepreneurship (Perkmann et al. 2013). It may also include exposing students to practical industrial problems and the joint supervision of doctoral research students (Santoro and Gopalakrishnan 2001; Ankrah and Al-Tabbaa 2015). Although much academic research has concentrated on the outputs associated with the creation and commercialisation of intellectual property, broader engagement activities may be a more valuable source of knowledge transfer to the private sector, and also a significant form of income for universities (Cohen et al. 2002; Perkmann et al. 2011a; Cesaroni and Piccaluga 2016; Schaeffer et al. 2018). However, it should be recognised that engagement is not purely about income generation, but is often a natural extension of core research activities (Perkmann et al. 2013). For example, it may be a source of learning for academics as they test their research in the field and obtain new insights (Lee 2000).

Commercial activities, on the other hand, are more likely to be motivated by pecuniary incentives for universities (D'Este and Perkmann 2011). Similarly, firms gain by: accessing new technologies and controlling the direction of university research (Bonarccorsi and Piccaluga 1994; Newberg and Dunn 2002); boosting research capacity, especially among small and medium sized enterprises (López-Martínez et al. 1994); and accessing human capital in terms of the most promising students or members of faculty (Feller et al. 2002; Perkmann et al. 2011b). Government research policies may also make collaboration a requirement for participation in some schemes (Howells et al. 1998).

Engagement activities differ in terms of the extent to which they are suitable for the transfer of tacit knowledge (Schartinger et al. 2001, 2002). Given the need for face-toface contact for the transfer of knowledge that cannot easily be codified (Lundvall 1992; Asheim and Gertler 2005), some engagement activities are likely to require the development of stronger network ties. Perkmann and Walsh (2007) categorise university-firm links 
on a scale dependent upon the degree of relational involvement required. At the high end are research partnerships, such as collaborative research; and research services including consultancy. At the lower end are transfer activities, such as the exploitation of patents through licensing agreements, as these are often largely market-based and do not require relationships to be built and maintained. Activities relating to the mobility of human capital between universities and industry, such as academic entrepreneurship and the creation of university spinoffs, generally fall in the middle, with Perkmann and Walsh (2007) defining these as requiring medium relational involvement. This is due to the individuals involved often maintaining relationships with their former university employers (Colombo et al. 2010). This means that the types of activities through which universities externally engage with the outside world are likely to impact on their structural position within knowledge networks. Given this, and the potential association of external engagement with network position outlined above, the two key hypotheses the analysis seeks to address are:

H1 There is significant variability in the extent to which universities are able to occupy central positions within university-industry networks.

H2 The forms of relational involvement employed by universities in their links with industry and other organisations will be significantly associated with the centrality of these universities within wider university-industry networks.

In terms of relational involvement, not all universities and their faculty are equally likely to engage in engagement and commercialisation activities due to their focus and capabilities (Ponds et al. 2010; Hewitt-Dundas 2012, 2013; Huggins and Kitagawa 2012). Furthermore, although commercialisation activities may originate from engagement activities, there may also be differences in the antecedents behind each (Perkmann et al. 2013). There is evidence that engagement activities are negatively related to university or department quality, potentially reflecting a lesser need to access finance from alternative sources (D’Este and Patel 2007; Ponomariov 2008; Ponomariov and Boardman 2008). However, Fantino et al. (2015) find that proximity to top-rated research departments, rather than universities in general, increases firm collaboration with universities. These findings are similar to those of Laursen et al. (2011), who find that proximity to low quality universities reduces the likelihood of local collaboration, and where proximity and quality are in conflict a preference for quality tends to take precedence. Potentially universities rated more highly in terms of research may have less demand for partnerships, but enjoy a higher supply of possible partners, leading to an ambiguous overall effect (Johnston and Huggins 2016; 2017).

Commercialisation activities, on the other hand, are positively associated with research quality (Di Gregorio and Shane 2003; O'Shea et al. 2005). More generally, established universities tend to be more research focused and may have a greater attraction for external organisations looking to exploit the knowledge generated by this research for commercial purposes, with newer universities often being weaker in terms of research output (Lambert 2003; Lockett, Wright, and Franklin 2003; Wright et al. 2006; Wellings 2008). Fundamentally, the knowledge creation capability of a university will be required to be of a quality and type that lends itself to potential transfer (Lee et al. 2001; Friedman and Silberman 2003; Ponds et al. 2010). This suggests the following: 
H2.1 The amount of funded research activity undertaken by universities will be significantly associated with their centrality within university-industry networks.

Given the benefits to firms from the commercial exploitation of knowledge (Cohen et al. 2002), and universities in terms of seeking additional funds (Perkmann et al. 2013), the commercial focus of a university may also play a role in determining network centrality. The outputs valued by colleagues are likely to influence the extent to which such collaborations are sought (Stuart and Ding 2006; Bercovitz and Feldman 2008; Haeussler and Colyvas 2011). This can work in both directions, whereby commerciallyoriented universities are regarded as being more likely to create research outputs with value to private firms (Di Gregorio and Shane 2003). However, a commercial focus may also lessen the chances of collaboration as universities limit or delay the dissemination of research results and/or, sharing them only with those that have funded the research (Argyres and Liebeskind 1998).

In general, technology transfer resources are likely to be positively associated with commercialisation, but there is less evidence of this influencing wider engagement activities (Siegel et al. 2003; Lockett and Wright 2005; Cesaroni and Piccaluga 2016; Schaeffer et al. 2018). Some evidence suggests that the presence of technology transfer offices is only a factor for larger firms when making decisions with regard to collaborative partners. In particular, policies relating to technology transfer, such as the proportion of royalties retained by faculty, may not just influence the likelihood of collaboration, but also the type of collaboration (Di Gregorio and Shane 2003). Therefore, commercial orientation may clearly affect the network position of universities, although there are multiple routes through which universities may commercialise knowledge. Two distinct routes are discussed in more detail below: direct exploitation via academic entrepreneurial spinouts (Djokovic and Souitaris 2008), and patenting allowing licensing to others (Baldini 2006).

Linked to the above findings that academic involvement in firms can influence the extent to which they may benefit from university knowledge, studies such as Colombo et al. (2010) and Stuart et al. (2007) also note that academic entrepreneurs may act as a conduit between universities and other firms. Their social ties (Roberts 1991; Murray 2004) and scientific backgrounds (Colombo and Piva 2008) may better position them to access and absorb university knowledge (Audretsch and Lehmann 2006). In doing this, other firms to which they are networked can gain from this knowledge after its transformation into a more commercialised form (Colombo et al. 2010; Aaboen et al. 2016). For universities, this means that the creation of entrepreneurial spinouts is likely to aid their ability to develop links with other firms.

H2.2 The number of spinouts generated by universities will be significantly associated with their centrality within wider university-industry networks.

Such spinout activity is found to be positively related: to intellectual eminence (Fini et al. 2017), including research profile (Lawton Smith et al. 2014); university policies on technology transfer; and the commercial orientation of research (Di Gregorio and Shane 2003; Berbegal-Mirabent et al. 2013; Farnstrand Damsgaard and Thursby 2013). Those university policies that have a key impact on spinout activity concern the proportion of royalties faculty receive from the licensing and equity investments made by universities in spinouts, which lowers start-up costs. The proportion of licensing royalties 
received by staff from patent activity is generally found to be negatively related to other forms of relational involvement such as spinout activity (Di Gregorio and Shane 2003), which suggests the following.

H2.3 Rates of patenting undertaken by universities will be significantly associated with their centrality within wider university-industry networks.

Finally, there are often considerable differences in the capability of universities to effectively transfer their knowledge, and of firms to effectively absorb such knowledge (Di Gregorio and Shane 2003; Lawton Smith and Bagchi-Sen 2006; Perkmann and Walsh 2007; Hewitt-Dundas 2012, 2013; Huggins and Kitagawa 2012; O'Reilly and Cunningham 2017). Also, the capacity to effectively engage in knowledge transfer forms part of the wider entrepreneurial capabilities of universities, as well as the capabilities of any respective knowledge or technology transfer offices (Carlsson and Fridh 2002; Chapple et al. 2005; O'Kane et al. 2015; Baglieri et al. 2018). Given this, external networking capability may also rely on the prestige and reputation of the institution (Shane and Cable 2002; Fritsch and Slavtchev 2007; Huggins et al. 2008; Santoro and Chakrabarti 2002; Schartinger et al. 2001, 2002), suggesting the following:

H2.4 The general status of a university will be significantly associated with its centrality within wider university-industry networks.

\subsection{The spatiality of open innovation}

Although open innovation is a concept originally developed to better understand the nature of knowledge flows across firms, as opposed to 'closed' flows of knowledge within firms, it is one that can also be applied at a more spatial level, in particular the nature of both intra regionally-bound flows of knowledge (closed regional innovation) and more interregional flows of knowledge (open regional innovation) (Huggins and Thompson 2014). Alongside the importance of the structural position of an actor within a network, its spatial and geographic position clearly remains of considerable relevance in terms of understanding patterns of regional innovation. Indeed, within debates concerning inter-organisational networks, the roles of space are recognised as increasingly important features of network structure and operation (Krätke 2010; Huber 2012b; Ter Wal and Boschma 2011; Aguiléra et al., 2012; Broekel et al. 2014; Balland et al. 2016; Knoben et al. in press; Ryu et al. 2018). A key feature of this discourse has long concerned the role of networks of spatially proximate and co-located external organisations, such as universities, R\&D labs, and other firms or individuals, within the innovation process (Mattes 2012). Whilst proximity results in increased knowledge flows, it may also present adverse effects related to involuntary knowledge spillovers, indicating additional spatial complexity related to openness and appropriability (Laursen and Salter 2014; Freel and Robson 2017).

Implicit in the argument stemming from observations of advanced regional economies is that the skills and technology gained through local interactions in knowledge-rich environments better prepares firms for obtaining knowledge from distant sources, allowing them to benefit more from overseas knowledge (Sturgeon 2003; Saxenian 2005; Ter Wal and Boschma 2011; Balland 2012). Indeed, alongside the recognised role of spatial proximity to network development, there is an increasing emphasis on the importance of 
understanding networks and knowledge flows in an environment that is simultaneously intra and inter-regional (Bathelt et al. 2004; Simard and West 2006; Andersson and Karlsson 2007; Agrawal et al. 2008; Lorentzen 2008; Van Geenhuizen 2008; Maggioni and Uberti 2009; 2011; Laursen et al. 2011; Broekel and Boschma 2012; Doran et al. 2012; Bouba-Olga et al. 2012; D'Este et al. 2013; Herstad and Ebersberger 2015; Bergé et al. 2017; Huggins and Thompson 2017; Huggins and Prokop 2017; Braunerhjelm et al. 2018; Sonmez 2018).

In general, the constraining effect of distance on knowledge flow and transfer is considered by some to be gradually diminishing, and there is increasing evidence of the heightened role being played by non-local knowledge sourcing networks in many places across the globe (Athreye 2004; Doloreux 2004; Garnsey and Heffernan 2005; Saxenian 2005; Bergé et al. 2017; Belussi et al. 2018; Sonmez 2018). Many firms do not acquire their knowledge from within geographically proximate areas, particularly those firms based upon innovation-driven growth where knowledge is often sourced extra-regionally (Davenport 2005; Drejer and Lund Vinding 2007).

The key aspect of these developments is that the knowledge base of many advanced regional economies is no longer necessarily local, but also positioned within more regionally open innovation and knowledge networks (Wolfe and Gertler 2004; Huggins and Izushi 2007; Lorentzen 2008; Cappellin and Wink 2009; Fitjar and Rodriguez-Pose 2011; Capello and Camilla 2013). There is also a growing school of thought that nonproximate actors are often equally, if not better, able to transfer strategically relevant and valuable knowledge across such spatial boundaries providing a high performing network structure is in place (McEvily and Zaheer 1999; Dunning 2000; Lissoni 2001; Dicken and Malmberg 2001; Davenport 2005; Palazzo 2005; Zaheer and Bell 2005; Teixeira et al. 2006; Torré 2008; Balland et al. 2016; D’Ambrosio et al. 2017; Sonmez 2018). This suggests that the relational factors determining the centrality of universities in networks with industry may differ when focusing on networks consisting of non-local links:

H3 The forms of relational involvement associated with the centrality of universities in university-industry networks embedded in a particular region will differ from those associated networks that cross regional boundaries.

Extant research on university-industry ties has produced some evidence suggesting that the co-location of research intensive firms and universities in the same region facilitates interactions that lead to innovative collaboration (Laursen et al. 2011; D'Este et al. 2013; Crescenzi et al. 2017; Davids and Frenken 2018). Given the current evidence base, it can be suggested that universities located in core regions with greater pools of large R\&D-intensive firms may have better opportunities to forge links with large R\&D players than their counterparts in more peripheral regions (Crescenzi et al. 2013; Vallance et al. 2018). Indeed, innovative regional economies are typically considered to be populated by research-intensive universities engaged in world-leading research (Drucker and Goldstein 2007; Lawton Smith 2007; Sainsbury 2007; Lawton Smith et al. 2014; D'Este and Iammarino 2010; Hewitt-Dundas 2012; Laursen et al. 2011; Howells et al. 2012; Huggins et al. 2012b).

These universities often play an important role in a region's innovation culture, for example Cambridge University and the biotechnology and IT clusters in the local area (Cooke 2002; Cooke and Huggins 2003; Hughes and Kitson 2012) and Stanford 
University within Silicon Valley (Saxenian 1994). Whilst a world-leading researchintensive university does not necessarily create a high-technology economy (Feldman and Desrochers 2003), universities undertaking world-leading research are also more likely to be members of national or global knowledge pipelines (Bathelt, Malmberg, and Maskell 2004). Less innovative regions tend to be organisationally and institutionally 'thin', with a lack of innovation-driven public or private sector entities, coupled with a high dependence on small and medium enterprises exhibiting low growth trajectories and operating within only fragmented connections to external sources of knowledge (Huggins and Izushi 2007; Ponds et al. 2007; Huggins and Johnston 2009).

The discourse on the role of universities as knowledge transfer institutions and key nodes in innovation systems is largely reliant on empirical work from exemplar regions; that is, those regions which are among the most innovative in the world (Saxenian 1994; Lawton Smith 2003; Gertler and Wolfe 2004; Owen-Smith and Powell 2004; Garnsey and Heffernan 2005; Lawton Smith et al. 2014; Reynolds and Uygun 2018). For every successful region, however, there exists many more 'ordinary' and less innovative regions (Howells 2005; Tödtling and Trippl 2005; Doloreux and Dionne 2008; Huggins and Johnston 2009). Furthermore, rising levels of national and transnational academic-industry partnerships demonstrate that neither firms nor universities consider knowledge flows to be necessarily spatially constrained (Huggins et al. 2008; Varga and Parag 2009). The increased reliance on wider spatial knowledge pipelines is reflected by the growing number of firms choosing to work with the best universities regardless of location, in order to take advantage of high talent pools, favourable intellectual property rules and government incentives for joint industry-university research (NSF 2006; Polenske 2007; D'Este and Patel 2007; D'Este et al. 2013). If this is the case, the spatial location of universities is unlikely to be a significant factor in determining the position of universities within the knowledge networks of universities:

H4 The regional location of universities will not be significantly associated with their centrality within wider university-industry networks.

Table 1 Summary Regional Innovation Index (2014), gross value added (GVA) per capita and number of universities by region

\begin{tabular}{lllllr}
\hline Region & $\begin{array}{l}\text { Summary Regional } \\
\text { Innovation Index } \\
2014\end{array}$ & $\begin{array}{l}\text { Rank } \\
\text { (regional } \\
\text { innovation) }\end{array}$ & $\begin{array}{l}\text { GVA per } \\
\text { head 2012 } \\
(\mathfrak{E})\end{array}$ & $\begin{array}{l}\text { Rank } \\
\text { (GVA per } \\
\text { head) }\end{array}$ & $\begin{array}{l}\text { Number of } \\
\text { universities }\end{array}$ \\
\hline East Midlands & 0.45 & 6 & 17,448 & 8 & 9 \\
East of England & 0.54 & 1 & 19,658 & 4 & 9 \\
London & 0.47 & 4 & 37,232 & 1 & 39 \\
North East & 0.43 & 8 & 16,091 & 11 & 5 \\
North West & 0.46 & 5 & 18,438 & 6 & 14 \\
Northern Ireland & 0.37 & 12 & 16,127 & 10 & 2 \\
Scotland & 0.45 & 7 & 20,013 & 3 & 15 \\
South East & 0.53 & 2 & 23,221 & 2 & 17 \\
South West & 0.48 & 3 & 19,023 & 5 & 13 \\
Wales & 0.42 & 10 & 15,401 & 12 & 12 \\
West Midlands & 0.43 & 9 & 17,429 & 9 & 12 \\
Yorkshire and The Humber & 0.41 & 11 & 17,556 & 7 & 11 \\
\hline
\end{tabular}




\section{Data collection and methodology}

Empirically, the network analysis presented in following sections is based upon links between universities and firms and other organisations within and across the regions of the UK. In this case, the 'region' is taken to be one of the 12 UK NUTS 1 regions (consisting of the standard classification of regions in the UK as shown by Table 1). At the time when the data for the study was collected there were 158 universities across the UK, with approximately one quarter of these located in London. South East England has the second highest number of institutions, followed by Scotland and North West England (Table 1). According to the UK Competitiveness Index (Huggins 2003; Huggins and Thompson 2013), across these 12 regions, the most competitive are Eastern England, London and South East England, as these are the only ones performing above the UK average in terms of a broad number of economic indicators. As shown by Table 1, Gross Value Added (GVA) per capita is highest in the most competitive regions. Also, it shows that based on the European Union's Summary Regional Innovation Index (Hollanders et al. 2014), the most competitive regions are generally also the most innovative.

To construct the sample dataset for this investigation, information was collected to create a unique database of firms and organisations interacting with UK universities between 2005 and 2008 via knowledge transfer activities. The database of interactions consists of information gathered from an analysis of university published documentation and annual reports. All the universities covered by the analysis provided information for the relevant years through written publically available annual reports and/or online sources. In most cases, these reports were prepared by the respective technology/knowledge transfer office within each institution. Therefore, they are those interactions known to them. As these offices are required to annually provide the government with official statistics on such interactions they should be represent a consistent sample across institutions, even though there will be instances of interaction where academics have interacted with industry that has been 'off-the-radar' of these offices.

For each university in the UK a review of these reports was undertaken for the 3-year period 2005-2008. This period was chosen as it provided a consistent number of institutions to analyse, since both prior to and following this period, there were a number of reconfigurations through mergers and other organisational changes. Also, the public sector funding landscape for research and knowledge exchange activities was relatively settled, meaning that there was not significant external noise that would potentially give misleading results. Furthermore, the independent variable indicators in terms of university characteristics and performance sourced from government statistics were indicators constantly recorded during this timeframe. For this period, the research team recorded the details of any active interactions with industry and other organisations (excluding other universities) listed that relate to three areas of activity, namely: (1) collaborative research-academic research undertaken in partnership with other organisations; (2) contract research-a transaction involving the provision of university research to an external partner (3) consultancy - application of existing knowledge in the form of advice or work to an outside party.

In each case, the name of the organisation was noted along with the dates the interaction covered, as well as any other defining characteristics of the interacting organisation. Following the initial completion of the dataset, for the private sector organisations included in the dataset, a number of business databases were mined that provided further details of the characteristics of these firms such as business size, location, and sector of activity. This principally consisted of the FAME database, but was supplemented where necessary by a 
range of internet and database search that provided additional business information. Importantly, this allowed the research team to confirm or identify the location of the interacting firm. In a very small number of cases where firms operated across multiple sites, and where it was not possible to identify the relevant location/site based on university provided documentation, the address of the UK headquarters of the firm was utilised. Fundamentally, therefore, data collection consisted of a two-stage process: (1) the names of firms interacting with universities during the period was ascertained via the information made publically available by universities; and (2) further details on the characteristics of these firms was sourced from the FAME database, and other internet sources if there gaps within the FAME database.

\subsection{Mode of analysis}

Based on the data outlined above, a network of links between UK universities and firms and organisations is constructed. Social network analysis software (Pajek 1.24) is utilised as a means of analysis and graphical representation of the ties held by universities (de Nooy et al. 2005). Social Network Analysis (SNA) is utilised to develop proxy measures of network centrality. The key SNA variable consists of betweenness centrality, which is established for all organisations contained within the database. Although there are a number of related centrality measures that could be utilised-such as degree centrality (Freeman 1977) and structural holes (Burt 2005) — betweenness centrality is generally considered to be one of the most robust measures of central positioning (Borgatti 2005), and is the measure adopted by a number of the most influential existing studies in the field (Owen-Smith and Powell 2004; Protogerou et al. 2013; Dong et al. 2017; Latorre et al. 2017; Martinus and Sigler 2017; Pan et al. 2018; Park et al. 2018; Sun and Cao 2018). Interestingly, there is a significant degree of correlation with the betweenness centrality indicator and other centrality measures, but given the use of betweenness centrality by other studies we decided to concentrate on this measure.

Betweenness centrality attempts to quantify the importance or prominence of an individual actor in a network (in the case of the following analysis this actor is considered to be a 'university', although it is acknowledged that such organisational actors comprise multiple human agents). Centrality measures consider an actor to be prominent if the actor is extensively involved in interactions with other actors in the network. In particular, betweenness centrality focuses upon the extent to which the actor might be able to control interactions between pairs of other actors in the network (Wasserman and Faust 1994). Betweenness centrality for actor $i$ is defined as:

$$
C_{B}(i)=\sum_{j<k} \frac{g_{j k}(i)}{g_{j k}}
$$

where $g_{j k}$ is the number of shortest paths (i.e. geodesics) from actor $j$ to actor $k$, and $g_{j k}(i)$ is the number of shortest paths from actor $j$ to actor $k$ that passes through actor $i$. Its minimum is zero, attained when actor $i$ falls on no geodesics. Its maximum is $(g-1)(g-2) / 2$ which is the number of pairs of actors not including actor $i$. The value of this indicator increases as the degree of centrality is higher (Wasserman and Faust 1994). In this case, the shortest path represents the number of links required for any university to be connected with another firm. As an illustration, in Fig. 1 university U1 is directly linked to firm F1 so there is only one link, but universities $\mathrm{U} 2$ and $\mathrm{U} 3$ only have an indirect link with F1 
Fig. 1 Illustrative example of links forming the betweenness centrality measure

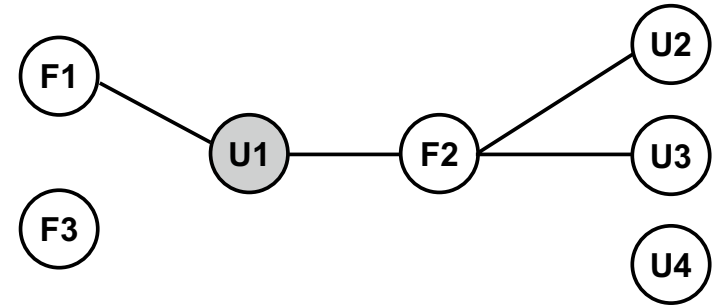

through firm F2 and U2, requiring three connections. Therefore, in this case U1 is more centrally positioned than $\mathrm{U} 2$ and $\mathrm{U} 3$ (university $\mathrm{U} 4$ and firm F3 possess no links and have zero centrality). Of course, in the reality this centrality is based on a measurement of all the links found. Clearly, the social network analysis stemming from this data could include other interactions such as firm-to-firm and university-to-university links. However, as seminal proponents of such analysis make clear, the 'total network' of any community stretches both within and beyond any imposed boundaries, and it always advisable to identify a particular segment or 'partial network' that is the focus of analytical attention (Mitchell 1969; Scott 2000). Only through the study of partial networks and particular relationships can content and meaning become clear (Mitchell 1969), and in this case the focus of attention principally concerns the networks that universities form with industry. Therefore, it makes methodological sense to concentrate on these particular links. Nevertheless, we acknowledge the edge and boundary effects this imposes on the analysis, as this is the case with any social network analysis whereby fixed boundaries are required to be enforced to aid meaningful study (Hunter et al. 2008).

\subsection{Methods for regression analysis}

In order to examine the factors that are associated with the betweenness centrality of universities within the constructed networks, we adopt a multiple regression approach. The independent variables included in the regressions cover general university characteristics, entrepreneurial and relational involvement, and regional innovation intensity. The general university characteristics relate to Hypothesis $\mathrm{H} 2.4$, and include a variable representing whether or not the institution held university status pre-1992 and total income per employee. With regard to the former, in the UK a marked division exists between those institutions that were universities pre-1992 and those that were formerly polytechnics or other colleges of higher/further education prior to 1992. This latter group are generally more teaching-intensive and have less of a tradition for undertaking research. These institutions generally have less prestige compared to their 'old university' counterparts and as such would be expected to have less attraction as network partners (Fantino et al. 2015; Laursen et al. 2011), potentially reducing betweenness centrality. This is not to suggest that all post-92 universities would be less valuable network connections for firms, or that they have not been progressive in their attempts to increase their outreach, but a strategic focus on increasing human capital, rather than research, may hinder this (Hewitt-Dundas 2012). Thus, their lower profiles may reduce their position in relative terms.

Similarly, the resources available within a university can be expected to be positively associated with the institution's accumulated knowledge, and therefore also positively associated with its network position (Wellings 2008; Shane and Cable 2002). Furthermore, it 
would also be expected that better funded universities with more resources per employee would be more likely to possess the resources to successfully manage their network ties (Shane and Cable 2002). To account for this, we include a gross income measure that covers the following sources: tuition fees and education contracts; funding body grants; research grants and contracts; other income; investment income; and donations and endowments. To make this a more accurate representation of the resources available to staff, income is divided by employment (full-time equivalent) to produce a measure of $£ 100,000 \mathrm{~s}$ of income per head.

Given the hypotheses proposed above, there is potentially a link between betweenness centrality and the entrepreneurial orientation of a university, with universities that are more engaged in knowledge commercialisation activities being more likely to hold prominent positions across university-industry networks. Over the last fifteen to twenty years, there has been more emphasis placed on trying to increase the value of university knowledge via government incentives (Soete 1999; Decter et al. 2007; Bozeman et al. 2015) and universities themselves (Chang et al. 2016; Sengupta and Ray 2017) as they seek to establish alternative income streams (Etzkowitz 2003; Jefferson et al. 2017; Castillo et al. 2018). As already indicated, many universities have undertaken activities to increase the number of university spinoff firms created, such as through the development of incubators or science parks (Phan et al. 2005). The formation of more direct links to the private sector in order to commercialise innovations has also played a role, and again physical infrastructure may help by allowing firms to locate in close proximity to the university, as well as through the development of knowledge transfer offices (Carlsson and Fridh 2002; Chapple et al. 2005).

There has also been a growing acknowledgement of the value of applied, as opposed to basic or pure, research (Lee et al. 2001; Friedman and Silberman 2003; Di Gregorio and Shane 2003; Ponds et al. 2010; Jefferson et al. 2017; Sengupta and Ray 2017; Schaeffer et al. 2018; Reynolds and Uygun 2018). Drawing upon Perkmann and Walsh's (2007) categorisation of engagement activities based on the degree of relational involvement, we use spin-offs per employee as a measure of medium relational involvement (Hypothesis $\mathrm{H} 2.2$ ), reflecting the direct commercialisation of knowledge by universities (Stuart et al. 2007; Colombo et al. 2010). This measure relates to the number of companies that are formally created to commercialise university generated intellectual property, with the number including both those where the university maintains a stake and those that are sold-off completely. As with income, this is scaled by the number of full-time equivalent employees.

The production of patents per employee (Hypothesis H2.3) is used to capture the extent to which innovative outputs with commercial potential are produced (Verspagen 2006). Patenting activity may be associated with more market-based interactions and low relational involvement, such as licensing agreements, with a smaller number of more exclusive interactions involved (Nelson 2004). As we are interested in the ability of universities to patent their research, which may be relatively rare, we use the cumulative portfolio of active patents to capture their on-going expertise in achieving this. This is scaled by fulltime equivalent employment to account for the size of institution.

The last pair of variables included represents the research environment of a university and high levels of relational involvement, which may reflect its ability to be positioned at the centre of a network (Zucker et al. 1998; Bathelt et al. 2004; van Looy et al. 2011). In particular, the knowledge production capacity of a university is represented in the regressions by research grants and contracts gained per employee (Hypothesis H2.1). Alternative measures such as the average score achieved by the university in the 2008 Research Assessment Exercise (RAE) were considered, but could not be included in the same regressions as research grants per head due to multicollinearity (there is also a greater correlation 
between pre-92 status and RAE outcome than is present when considering research grants per head and pre-92 status). Research grants per head was included not just for publicallyfunded pure research, but also contracts with industry associated with research partnerships and research services that require significant relational involvement (Perkmann and Walsh 2007). This measure, therefore, includes income from research councils, government and international bodies, as well as contract research for public, third, and private sector organisations. It is measured in $£ 1000$ s per full-time equivalent.

The locational measure for regional innovation is captured by the EU's summary regional innovation index (Hypothesis $\mathrm{H} 4$ ), which uses a variety of indicators to capture the enablers, firm activities, and outputs associated with greater innovation (Hollanders et al. 2014). The regional innovation index forms part of the Regional Innovation Scoreboard (RIS), which assigns the NUTS1 regions of much of the EU into one of four categories of decreasing innovative performance: innovation leaders; innovation followers; moderate innovators; modest innovators. The RIS is generated from 11 indicators covering: enablers (population education; R\&D expenditure as a percentage of GDP); firm activities ( $R \& D$ expenditure in the business sector as a percentage of GDP; non-R\&D expenditures on innovation as a percentage of turnover for SMEs; percentage of SMEs innovating; percentage of innovating SMEs collaborating with others; patent applications per billion Euro GDP); outputs (percentage of SMEs producing product or process innovations; percentage of SMEs introducing marketing or organisational innovations; percentage of employment in medium-high or high tech manufacturing, or knowledge intensive services; percentage of SME turnover from products or services new to market and new to the firm). Table 2 presents the descriptive statistics and Pearson correlation coefficients for the dependent and independent variables. It is clear from the simple statistics that there is considerable variation in the betweenness centrality measures, with a coefficient of variation of 1.47 for Betweenness Centrality and 1.53 for Inter-regional Betweenness Centrality. Similarly for the independent variables patents per employee (coefficient of variation $=2.70$ ) and spinoffs per employee (coefficient of variation $=1.31$ ) it appears that a small number of universities are accounting for a relatively larger proportion of all patents and spin-offs. The correlations between the independent variables do not appear to indicate any issues of multicollinarity, with the most strongly related being the Pre-92 dummy and spinoffs. Variance inflation factors (VIF) confirm this, with the maximum value of 2.88 being for research grants, well below conventional cut-off levels.

The regressions were initially run with only the general university characteristics included (Model 1).

$$
y=\beta_{0}+\beta_{1} \text { Pre } 92+\beta_{2} \operatorname{Inc}+\varepsilon
$$

Betweenness centrality ( $y$ ) is assumed to be associated with Pre-92 status (Pre92) and total income per employee (Inc). This, therefore, relates to Hypothesis H2.4.

The entrepreneurial orientation variables are added to produce Model 2, as these may be expected to reflect the willingness of the university to form links to achieve its objectives and operate in a less traditional manner (Etzkowitz 2003).

$$
y=\beta_{0}+\beta_{1} \text { Pre } 92+\beta_{2} \text { Inc }+\beta_{3} \text { Patent }+\beta_{4} \text { Spin }+\varepsilon
$$

The addition of patents per full-time employee (Patent) and spinouts per full-time employee (Spin) allows for Hypotheses $H 2.3$ and $H 2.2$ to be tested respectively.

Model 3 adds the research environment variables for the university and region. This allows us to determine whether or not any significant factors from the general characteristics 


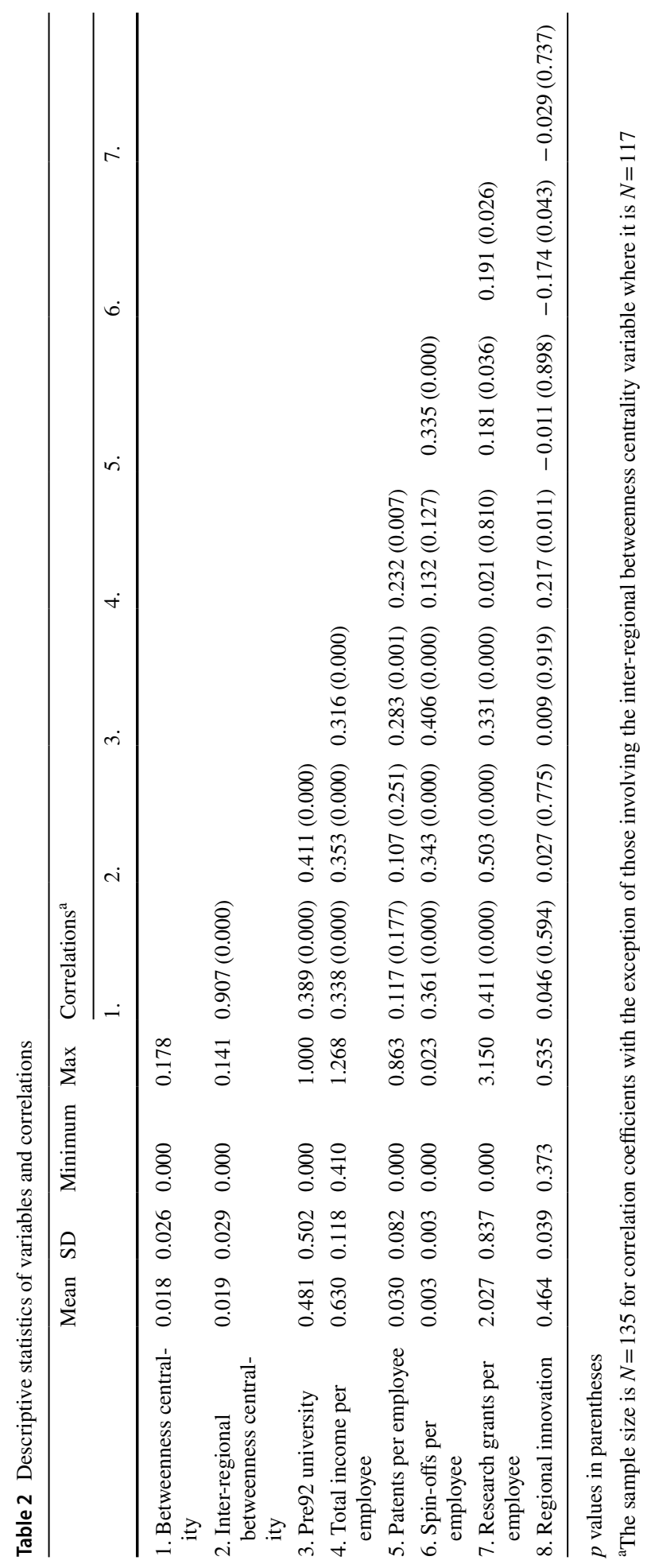


or entrepreneurial orientation of universities remain when the potential knowledge contained within these institutions and the wider regional environment is accounted for.

$$
y=\beta_{0}+\beta_{1} \text { Pre } 92+\beta_{2} \text { Inc }+\beta_{3} \text { Patent }+\beta_{4} \text { Spin }+\beta_{3} \text { Grant }+\beta_{4} \text { RegInn }+\varepsilon
$$

The inputs into the knowledge creation process in terms of grants per full-time employee (Grants) and regional innovation (RegInn) allow Hypotheses H2.1 and $H 4$ to be tested.

As noted above, the descriptive statistics imply that there may be issues relating to outliers or heteroscedasticity influencing results, as it appears that there are some universities with particularly high levels of betweenness centrality, spinoff activity, and research grant capture. Although we initially run the regressions using ordinary least squares, Breusch and Pagan (1979) tests for heteroscedasticity indicates that the error term may be related to all but the patents measure and regional innovation (simultaneous test Betweenness Centrality $\chi^{2}=241.3$, d.f. [6], $p$ value (0.000); Inter-regional Betweenness Centrality $\chi^{2}=100.1$, d.f. [6]. p-value $=(0.000))$. To account for this, all results reported in the next section use White's (1980) robust standard errors to account for the heteroscedasticity. As this does not account for the impact on the estimates of the coefficients, we also produce results using robust regressions where weights are inversely imposed relative to errors (Andrews et al. 1972). The disadvantage of such an approach is that outliers can be completely excluded from the analysis where a weighting of zero is imposed. These results are discussed where differences exist, but not reported for preservation of space. These results are available from the authors on request.

A further methodological factor given the issue at hand is that different universities are in effect contained within different clusters, i.e. their regions. This can produce incorrect results due to serial correlation between those universities located in the same region. This positive correlation between regional universities tends to lead to standard errors being biased downwards and the significance of regression coefficients being overstated, described as alpha bias (Cohen et al. 2003). In order to account for this, a multi-level mixed effects model is utilised. This approach allows a combination of both random and fixed effects. The fixed effects are estimated directly, whilst the random effects are incorporated in this case as random intercepts, so that all universities within the same region share the same random intercept. The regression takes the following form:

$$
y=X \beta+Z u+\varepsilon
$$

where $y$ is the betweenness centrality of universities. $X$ is a matrix of the university characteristics discussed above, with $\beta$ the estimated fixed effects coefficients. The random element is $Z u+\varepsilon$ made up of the random effects $(u)$ covariate matrix for these effects. The error term is assumed to be normally distributed with a mean of zero and variance matrix $\sigma_{\varepsilon}^{2} R$. The residual variance parameters are captured by $R$. The random intercept is not directly estimated, but is characterised by the variance-covariance matrix $G$. It is assumed that $u$ and $\varepsilon$ are orthogonal.

$$
\operatorname{var}\left[\begin{array}{l}
u \\
\varepsilon
\end{array}\right]=\left[\begin{array}{cc}
G & 0 \\
0 & \sigma_{\varepsilon}^{2} R
\end{array}\right]
$$

The advantage of such an approach is that multi-level models produce more efficient estimates of coefficients than single level alternatives, such as with Generalised Equation Estimation (GEE) and insights can be gained into differences at the group (regional) level. However, such an approach is only suitable where sample sizes are large enough at all levels, so a small number of groups-for example, examining relationships for universities in just two regions - may not be appropriate. Equally, estimation for regions with relatively 
small numbers of universities, such as Northern Ireland, may be problematic. To account for this and check for the robustness of results, we also produce ordinary least squares estimations with standard errors robust to the clustering of observations, but which do not account for the impact of clustering on the efficiency of estimates. In addition, we run GEE results that allow population averaged estimates to be produced where observations are not assumed to be independently distributed, thus allowing for clustering (Liang and Zeger 1986). Specifications are also run using standard errors adjusted for heteroscedasticity. As with the robust regression results discussed above, we do not present these results in full, but comment where significant differences exist. These results are available from the authors on request.

Accounting for Hypothesis H4, all sets of regressions are conducted for overall betweenness centrality and inter-regional betweenness centrality (i.e. centrality based on a network of inter-regional links only) as it is conceivable that those characteristics associated with engaging with regional and non-regional actors may differ given the importance of proximity found for some potential collaborators (Rosa and Mohnen 2007; Fantino et al. 2015).

Although some measures, such as Pre-92 status are exogenous, for some measures it is not possible to determine the direction of causality. The knowledge creation activities of universities may determine a university's position in a network, as others seek to access its knowledge. However, over time its position in networks would also be expected to support these knowledge creation activities. It would be reasonable to assume that both processes will be present, with the former likely to be a more rapid process, with new connections forged as hypothesised above, whilst the advantages from such connections will require more time to nurture and reach fruition.

\section{Results of the network analysis}

Figure 2 presents the network as a whole, with the black nodes representing university actors and the grey nodes firms and other organisations. It is clear that there are a number of universities that occupy highly central positions within the network based on their links with a number of firms and other organisations that are themselves in positions of high centrality. Beyond this, others are more relationally distant from the centre and are generally less well connected to the network.

Overall, 137 universities were identified as having at least one tie with a firm or other organisation involving one or more of the forms of interaction indicated above. In total, 8479 organisations were identified as having links with the universities, with the large majority $(86.5 \%)$ concerning private sectors firms. A further $5.1 \%$ of organisations are government establishments (principally, departments, agencies, executives, councils, the police force, and the National Health Service), and another $8.4 \%$ social enterprises, nonfor-profit concerns and charities (within the analysis non-private sector firms are referred to as 'other organisations'). Across the private sector 7334 establishments are represented, covering 8335 links, with the majority of the firms being small in size $(61.2 \%)$.

Figure 3 presents an illustration of the core sub-network, highlighting the principal universities and firms constituting the network, in particular those with the highest betweenness centrality. From the university perspective, those actors at the centre of the network are the University of Cambridge (betweenness centrality $(\mathrm{BC})$ score $=0.18$ ), University College London $(B C=0.12)$, Imperial College London $(B C=0.10)$, the 


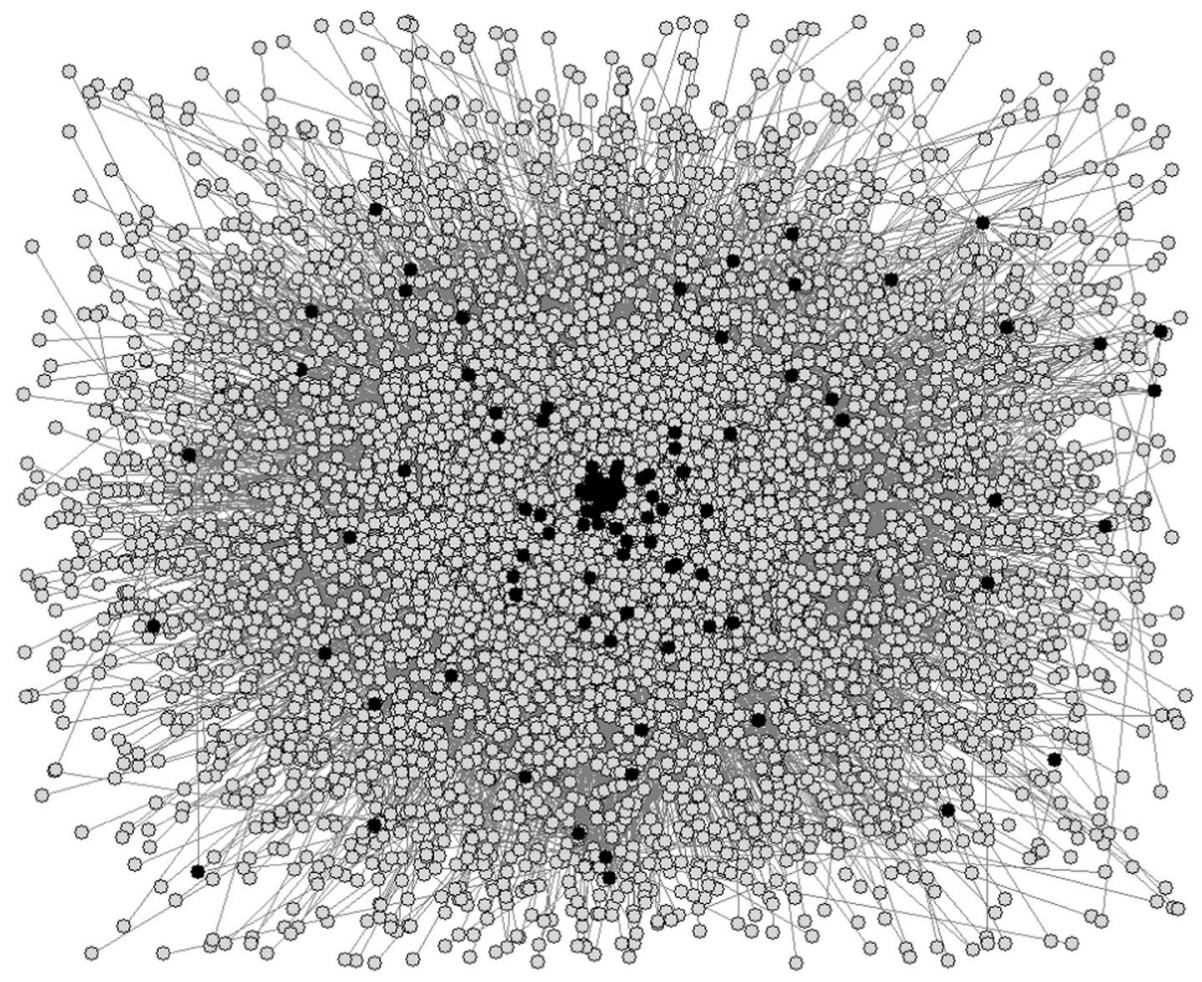

Firms and other organisations

- Universities

Fig. 2 University links with firms and other organisations - the full network

University of Birmingham $\mathrm{BC}=0.10$, and the University of Bath $(\mathrm{BC}=0.08)$. These universities also represent leading and highly research-focused institutions, with an onus on high rates of knowledge creation and production (Huggins et al. 2008). In this case, it is noticeable that the University of Cambridge possesses a considerably more influential and central position within the network than all the other universities represented. Furthermore, the most established universities (those institutions existing as universities prior to 1992) have, on average, a betweenness centrality score that is 3.7 times higher than those institutions that were granted university status in the post-1992 period.

From the perspective of firms within the network, the most influential actors are Rolls-Royce $(\mathrm{BC}=0.066)$, GlaxoSmithKline $(\mathrm{BC}=0.045)$, $\mathrm{BP}(\mathrm{BC}=0.031)$, BAE Systems $(\mathrm{BC}=0.030)$, $\mathrm{BT}(\mathrm{BC}=0.030)$, and Pfizer $(\mathrm{BC}=0.029)$. In general, these firms consist of large establishments that are among the UK's most R\&D-intensive private sector companies (BIS, 2010). Despite these large firms holding the most prominent positions, small firms account for the majority of private sector links with universities (58\%), although larger firms tend to have a higher mean average number of links with universities. In terms of sector, firms in the manufacturing sector account for $59.4 \%$ of establishments and $58.7 \%$ of links, with the services sector covering $26.6 \%$ of firms and 


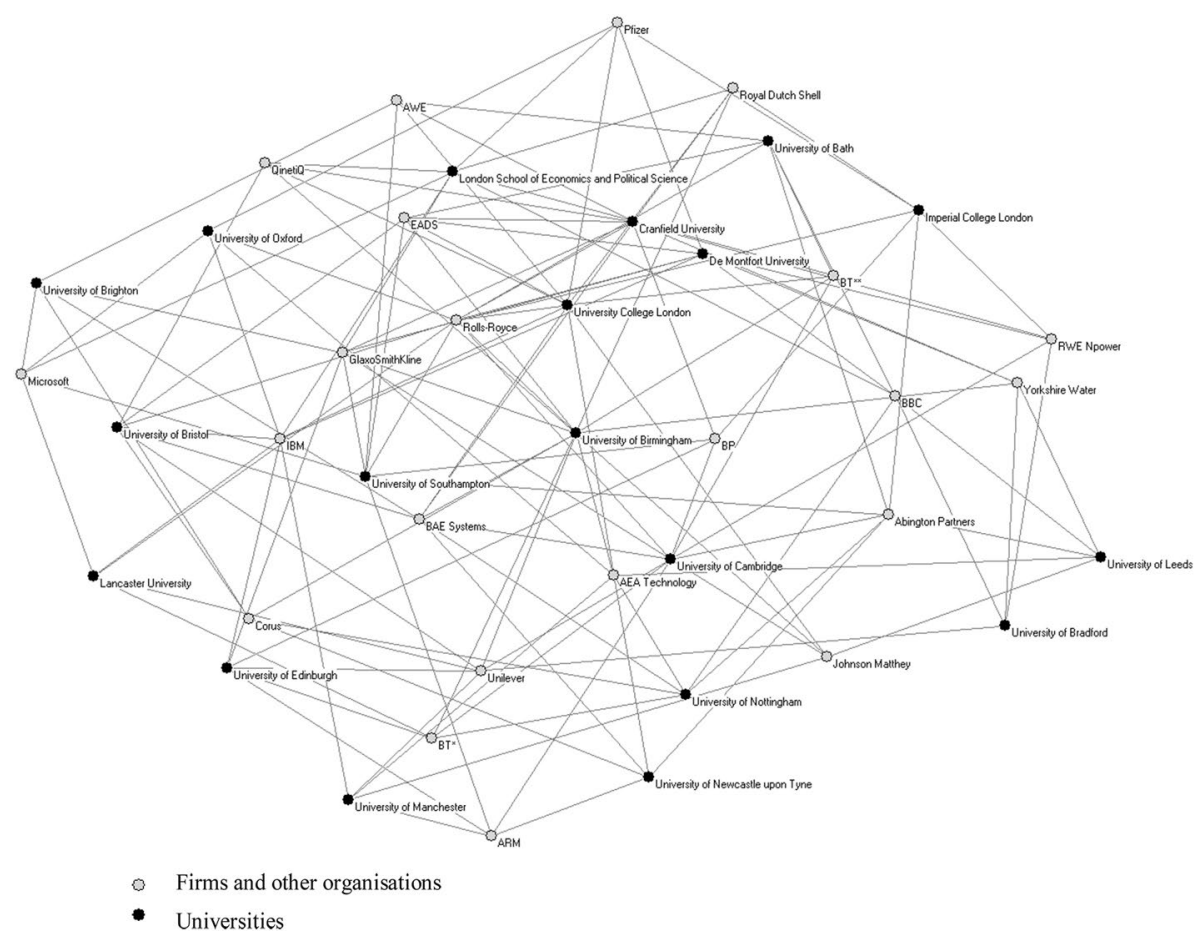

Fig. 3 University links with firms and other organisations- the core sub-network

$27.4 \%$ of links, respectively, with other sectors accounting for the remainder. A further 1567 links are identified for the other organisations with which universities interact, resulting in the network as a whole consisting of a total of 9902 links. As may be expected, a significant proportion of the links with other organisations (31.2\%) concern those located in London, with the South East, South West and Scotland having the next highest number of representative organisations.

In terms of the general characteristics of the network across regions, London accounts for 31 of the 137 universities with known links, with these universities further accounting for $15 \%$ of the total links within the network, followed by the South East $(11.4 \%$ of links), the East of England (10.3\%) and the North West (10.1\%). Universities in Northern Ireland (2.1\%), Wales (3.4\%) and the North East (5.8\%) account for the lowest number of links. Universities in the East of England have the highest number of links per university (126.9), followed by universities in the North East (115.80) and the West Midlands (108.0). Universities in Wales (30.4), London (47.6) and Scotland (58.2) have the lowest average number of links per institution. Overall, there is considerable variation across regions in the proportion of links that are held by universities with firms and organisations within and outside their region. For example, for universities in Northern Ireland, the West Midlands, and South East England the largest proportion of links are with organisations in the same region, whilst for universities in the East Midlands, London, the North East, the South West and Wales the majority of links are with organisations outside their respective region.

Figures 4, 5 and 6 illustrate the configuration of the network generated by universities across each of the twelve regions based on the same categorisation stemming from 
East of England (Innovation Rank 1)

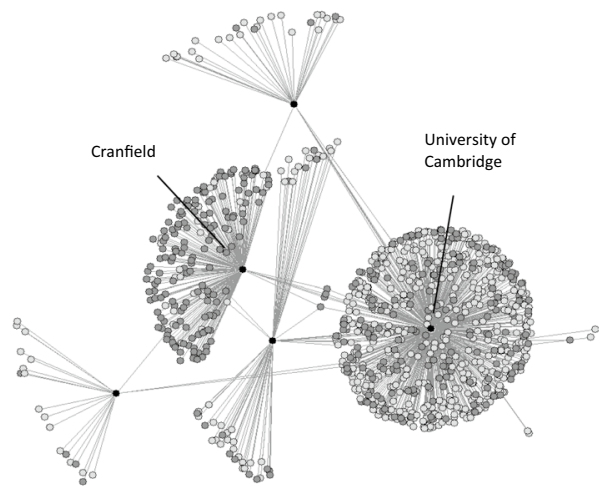

South West of England (Innovation Rank 3)
South East of England (Innovation Rank 2)

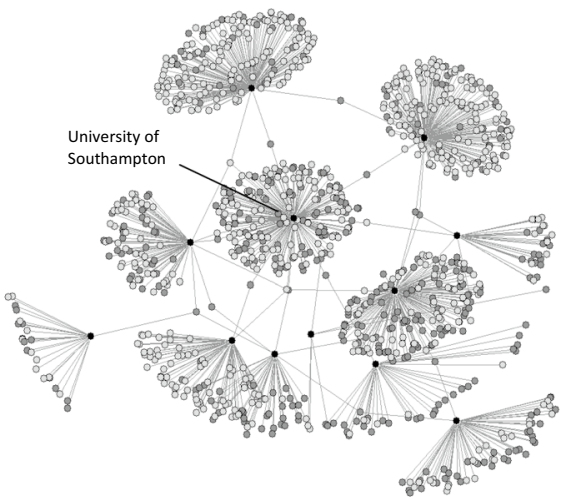

London (Innovation Rank 4)

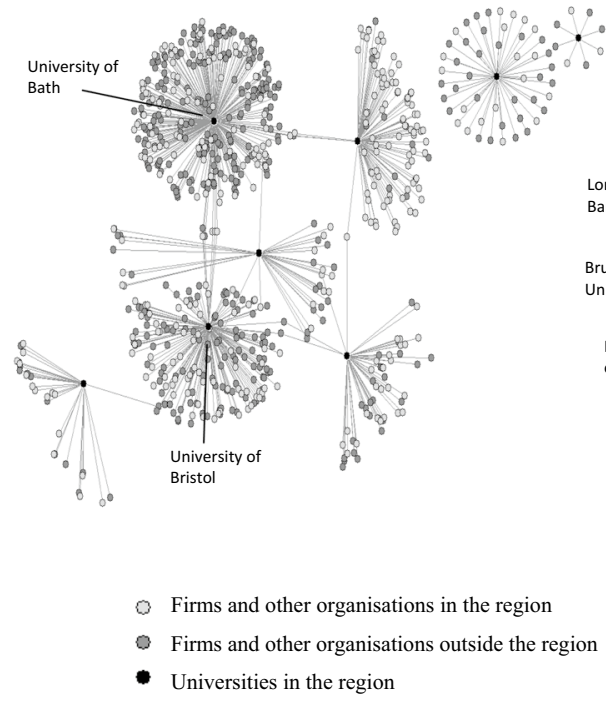

Fig. 4 Networks of universities in leading innovation regions

the EU's Regional Innovation Index. In this case, the black nodes denote universities in the respective region, the light grey nodes firms and other organisations in the region, and the dark grey nodes firms and other organisations outside the region. Across the three figures there is a trend for the networks to become thinner in the less innovative regions. The clustering around particular leading universities is quite pronounced, and in the case of the four leading regions shown in Fig. 4 it is clear that there is a cadre of universities that not only act as strong network entrepreneurs, but also as 'regionally open innovators', given that they possess significant links with organisations not only in their own region, but also other regions. The same patterns can also be found for universities located in regions with more moderate patterns of innovation (Fig. 5), whilst in the case of universities in the weaker innovation regions there is a lower density of linkages (Fig. 6). 


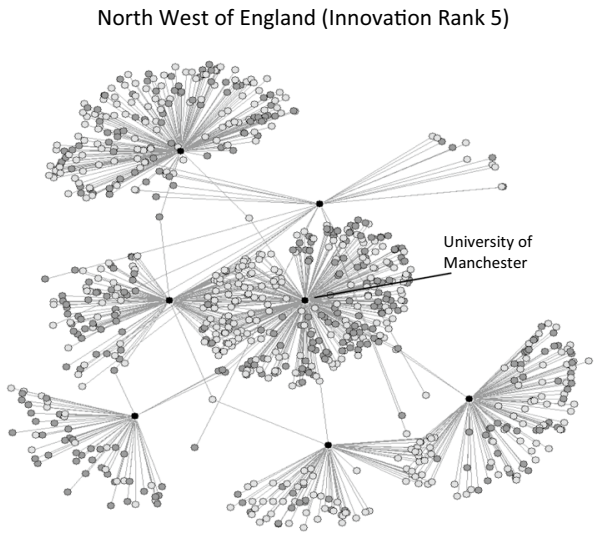

Scotland (Innovation Rank 7)
East Midlands (Innovation Rank 6)

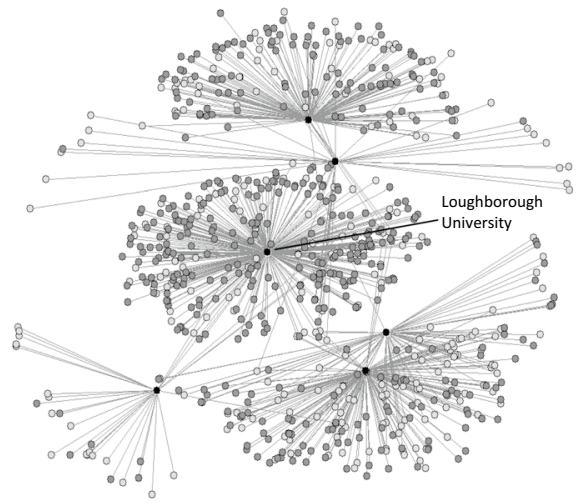

North East of England (Innovation Rank 8)

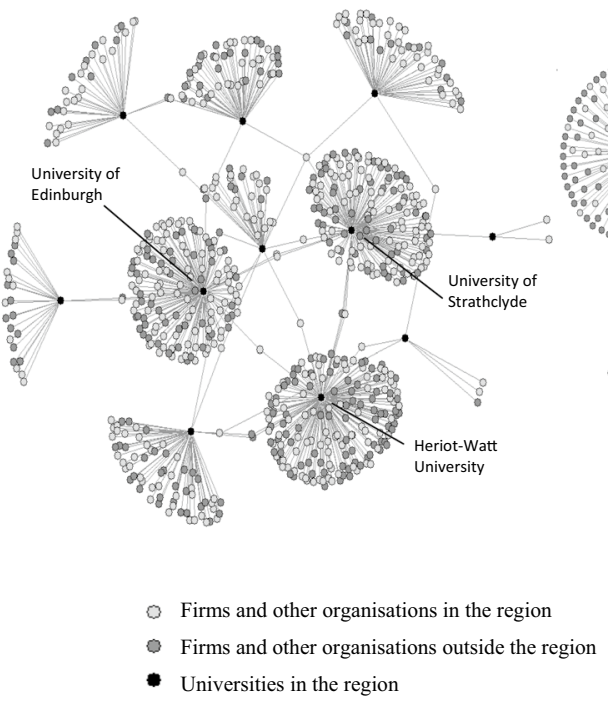

Fig. 5 Networks of universities in moderate innovation regions

One of the most interesting features of these network diagrams is the extent to which there are bridging connections across clusters and regions, with the level of connectivity across clusters being an indication of the extent to which knowledge is diffused within and between regions. This bridging appears to be stronger in leading regions, where cross-cluster connections are more developed. In some of the weaker regions, we see not only the thinness of network connections, but also a lack of depth to these connections.

Given the increasing interest in understanding the role of flows of knowledge across regions as a driver of regional innovation, it is instructive to focus attention specifically on the network formed solely by ties across regions. This network covers 134 universities and 3767 firms and organisations. These actors can be considered to be the key boundary spanners that bridge and connect flows of knowledge across regions, and those at the heart of promoting regionally open innovation. As shown by Fig. 7, these actors predominately involves the same group of universities that form the core of the most centrally positioned 

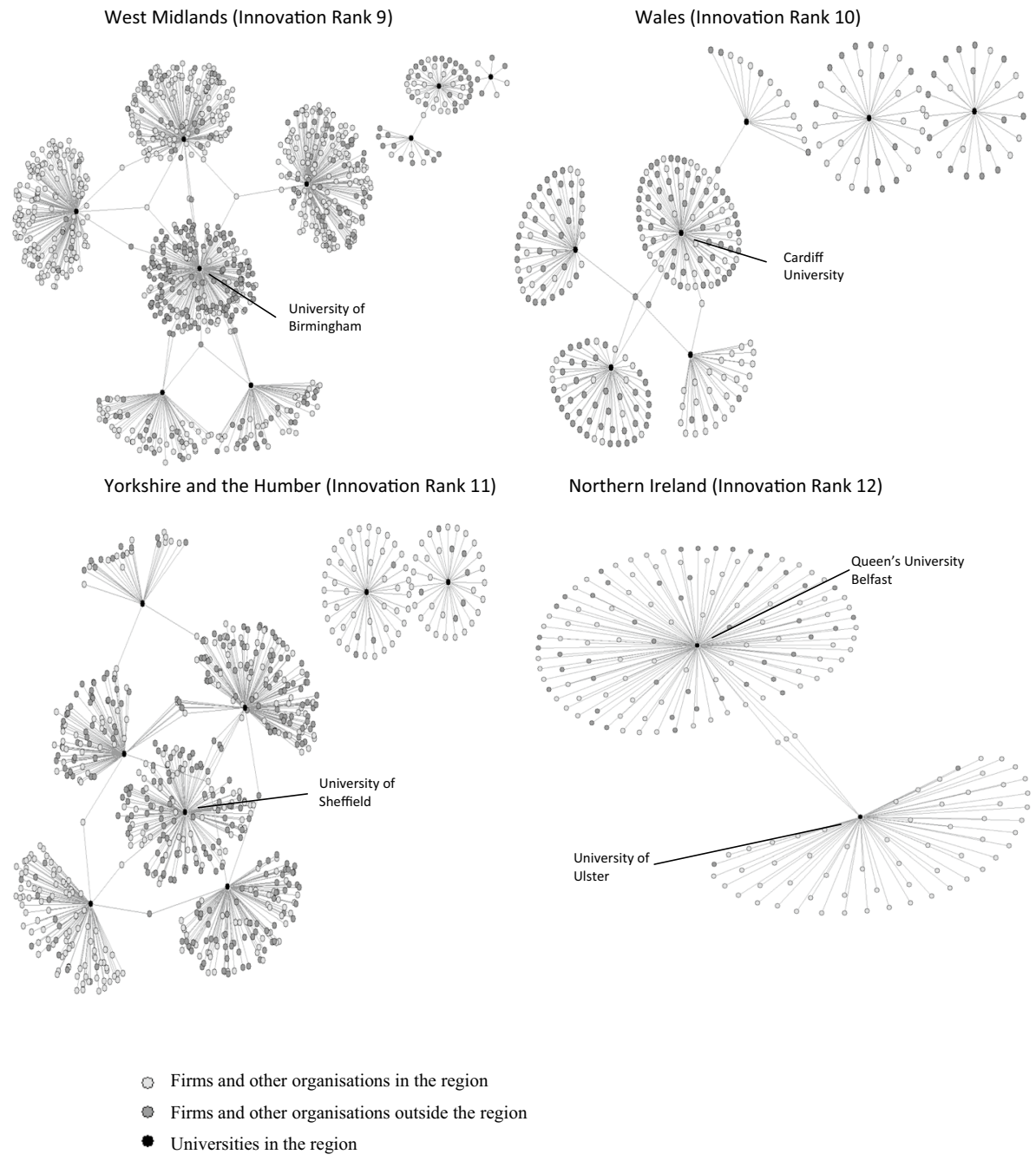

Fig. 6 Networks of universities in lagging innovation regions

universities overall. However, in this case it is Imperial College London, as opposed to Cambridge University, that shows the highest betweenness centrality, possibly suggesting Cambridge University's role as a more spatially clustered network entrepreneur and open innovator.

\section{Results of the regression analysis}

The results presented above suggest that betweenness centrality will be greater for those larger higher profile older universities with greater income levels. As other studies have noted, this could reflect the continuing importance of research profile and intellectual 


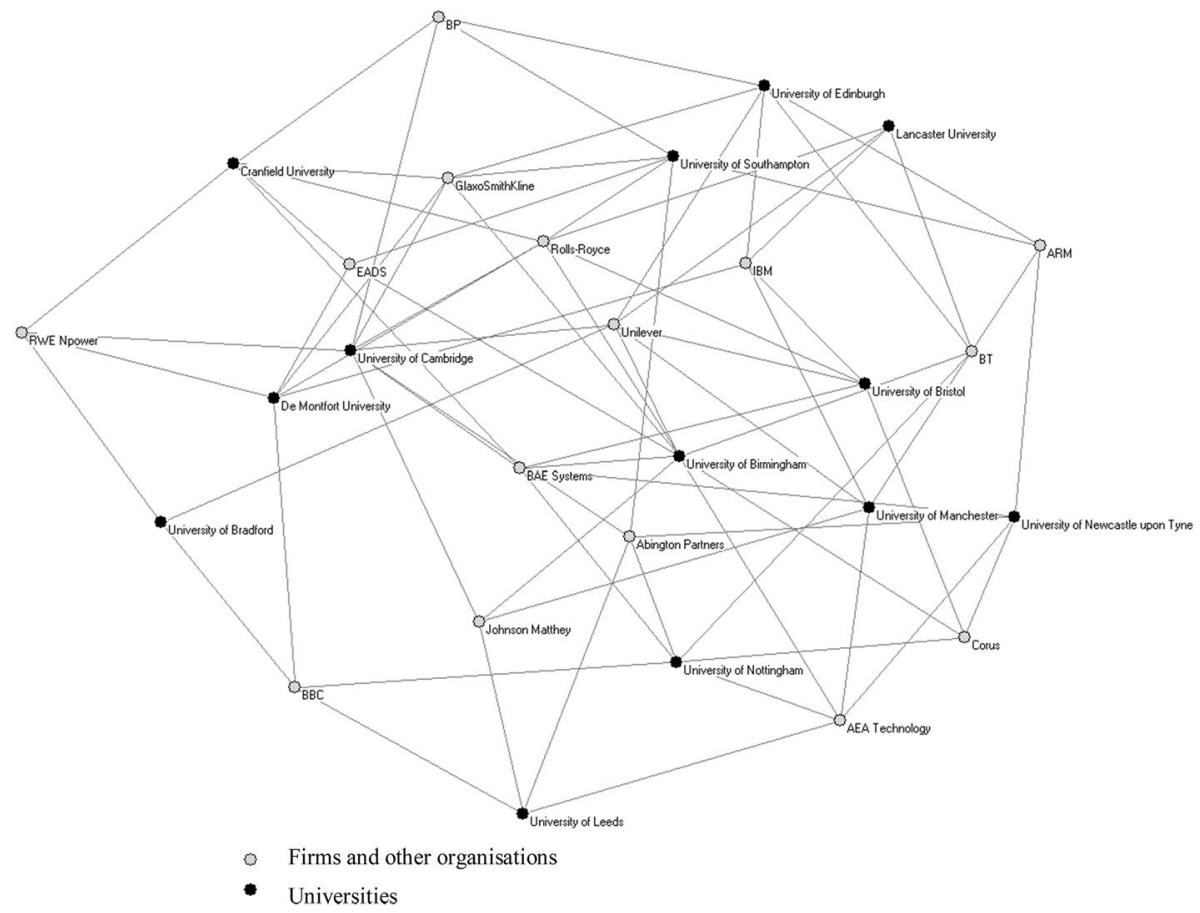

Fig. 7 University links with firms and other organisations- the inter-regional core sub-network

eminence in forming collaborations and attracting resources (Fantino et al. 2015; Laursen et al. 2011), and/or the quality of the research being generated (Zucker et al. 1998). However, the results also suggest that, contrary to the findings of some studies, any reduced need (demand) for top universities to form collaborations is not sufficient to offset increased opportunities (supply) (D’Este and Patel, 2007, Ponomariov, 2008; Ponomariov and Boardman, 2008; Johnston and Huggins 2016, 2017).

Overall, the regressions presented in Table 3 suggest that around 28 percent of the variance in betweenness centrality can be accounted for by the explanatory variables. Although with different specifications, this is a similar level of variance explanation as found in studies looking at the likelihood of firms collaborating with universities (Fantino et al. 2015). This is confirmed by likelihood ratio tests (LR-tests) comparing Model 2 with Model 1 which is significant at the 1 per cent level.

In Table 3, Model 1 suggests that older universities display higher levels of betweenness centrality. These results in combination appear to be consistent with the findings of others, e.g. Shane and Cable (2002), which indicate that the formation of network ties will be related to the prestige and reputation of the university, supporting Hypothesis H2.4. Being a Pre92 university raises betweenness centrality by 0.619 standard deviations (Model 1). It is also clear that the betweenness centrality of a university is significantly related to relational involvement when captured by spin-off activity (Hypothesis H2.2). When introduced, a 1 standard deviation increase in spinoff activity per full-time employee raises betweenness centrality by 0.23 standard deviations. Going from the lowest level of spinouts per employee, which is none of over the period (universities such as Bishop Grosseteste University and University of East London) to the highest level (0.023 per full time 


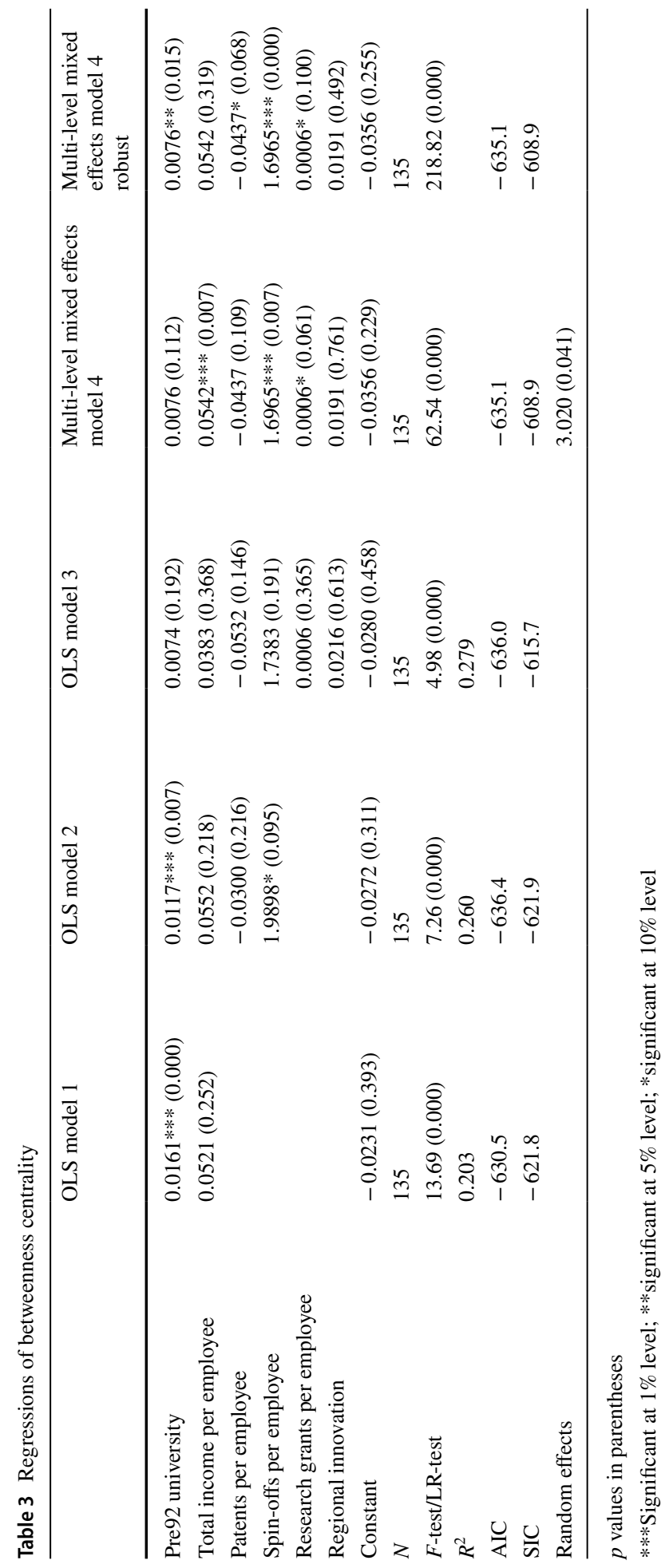


employee in the School of Pharmacy) raises betweenness centrality by 1.76 standard deviations). It is understandable that spinoffs may help universities to form network ties as they retain interaction, but also engage with other partners in the private sector (Pérez Pérez and Martínez Sánchez 2003). Another important factor that may be associated with betweenness centrality is the role that such spinouts play in connecting universities to other local firms (Colombo et al. 2010). Although spinoff activity reflects the development of commercialisable innovative outputs (Lee et al. 2001; Ponds et al. 2010), there is weak evidence that commercialisable research in the form of patents reduces betweenness centrality (Hypothesis H2.3). As others have suggested, this may reflect the restrictive arrangements associated with intellectual property protection (Argyres and Liebeskind 1998). Research grants per employee displays some evidence linking it to centrality in Model 3 (Hypothesis H2.1). This influence is much smaller than that found for spinout activity where a 1 standard deviation increase in research grants per employee raises betweenness centrality by 0.02 standard deviations. Similarly, controlling for research grants per employee results in patents becoming significantly associated with centrality in some models, and takes a negative coefficient.

Interestingly, and supporting Hypothesis H4, regional innovation has no significant association with betweenness centrality. Regressions run with alternatives of GVA per capita and R\&D expenditure per capita also found no significant relationship with betweenness centrality. The results are contrary to Crescenzi et al.'s (2013) findings, and instead suggest that large universities will be able to develop and maintain their network ties regardless of the local environment. This may reflect the increasing pattern of innovative firms seeking the best quality knowledge, and if such knowledge is available in close proximity they will utilise these sources, but otherwise they will look geographically further afield (Davenport 2005; Drejer and Lund Vinding 2007). This may be particularly the case with larger knowledge intensive partners that have higher absorptive capacity, with the quality of knowledge rather than proximity being of primary importance (Laursen et al. 2011; Fantino et al. 2015). The results also suggest that when a clustering effect—rates of regional university innovation and networking - is taken into account income per employee becomes significant at the 1 percent level, but only when not adjusting standard errors for other sources of heteroscedasticity (Model 4). It is where both clustering and robust standard errors are used that the weak negative relationship for patents is found (Model 5). In absolute terms, the effect of patenting activity on betweenness centrality is around half as strong as the effect of spinout activity, with a one standard deviation increase in patenting lowering betweenness centrality by 0.137 standard deviations. At the regional level, the estimated random effects indicate the leading regions to be the West Midlands (0.00457), South West (0.00361) and East of England (0.002613), and at the other end of the spectrum is London $(-0.00734)$ followed by Wales $(-0.00282)$ and Scotland $(-0.00234)$. In the case of London this may reflect the extreme mix of higher education institutions present, ranging from Imperial College London to smaller specialist colleges such as Trinity Laban Conservatoire of Music and Dance.

Alternative estimation methods all confirm spinout activity as being positively associated with betweenness centrality. With the exception of the robust regressions, being a Pre92 university is also found to be positively associated with betweenness centrality. The negative effect of patenting activity is never significant at more than the $10 \%$ level and is only confirmed by the GEE regressions with robust standard errors. Similarly, only one alternative estimation approach, GEE without robust standard errors confirms the impact of research grants. 


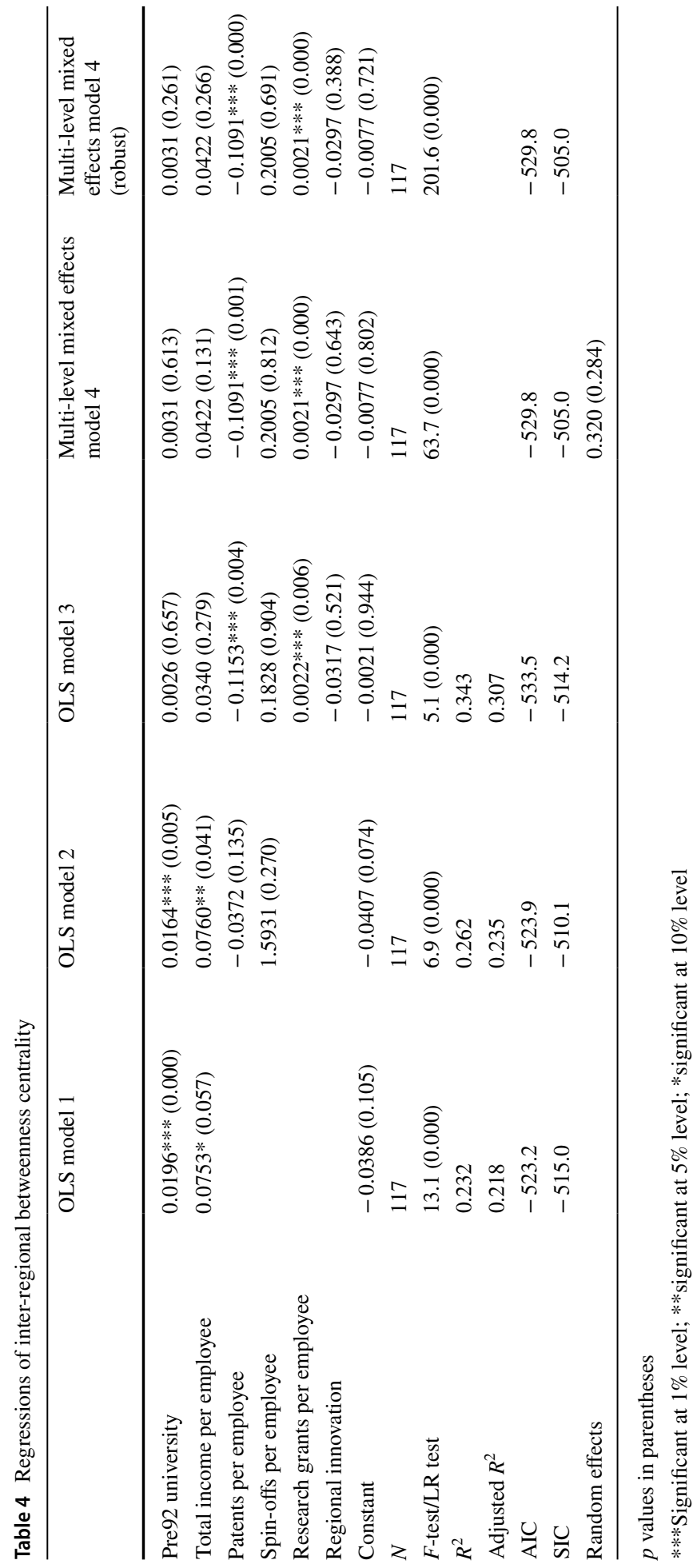


When considering inter-regional betweenness centrality (Table 4) the regressions explain a slightly higher proportion of the variance (30.7 per cent in Model 3) than was found to be the case for the overall measure of betweenness centrality (27.9 per cent in Model 3). The AIC suggests that Model 3 is most appropriate. As with the overall measure of betweenness centrality, there is evidence in Models 1 and 2 indicating that more prestigious better resourced universities are best placed within the network (Hypothesis H2.4). However, these characteristics become insignificant when research grants are introduced in Model 3. When considering less geographically proximate network ties, spinoffs are not significant (Hypothesis H2.2). When research intensity is included in Model 3, there is evidence to support Hypothesis H2.1, i.e. research grants and contracts per employee enable the formation of links to extra-regional knowledge pipelines. This effect is quite small in contrast to the spinout effect found for the overall betweenness centrality, but around three times as large as the impact of research grants on the overall measure, with a 1 standard deviation increase in research grants per full time employee increasing inter-regional betweenness centrality by 0.063 standard deviations.

The lack of significance of income per employee and university status prior to 1992 in Model 3 may reflect the fact that positions within networks beyond the university's own region are affected by prestige, with it being prestige and reputation in terms of research that is key rather than wider scale and history. As before, a focus on commercialisable research in terms of patent outputs generates a significant negative relationship when broader research prestige is accounted for (Hypothesis H2.3). This indicates that the formal protection of intellectual property by universities may negatively influence their centrality in networks that are organised over a significant physical distance. In other words, a lack of openness with regard to knowledge access constrains the positioning of universities within these networks. This is a relatively large effect as a 1 standard deviation in patents per fulltime employee lowers inter-regional betweenness centrality by 0.33 standard deviations, approaching two and half times as large an impact as found for the overall betweenness centrality measure.

No clustering effect is evident for the inter-regional betweenness centrality regressions, suggesting that regional location has little association with centrality. The use of different estimation approaches confirms the results above for patents and research grants with the exception of the robust regression results. This may reflect a small number of outliers driving the results. Those universities totally excluded by the robust regressions are most frequently the larger red brick universities established in the late 19th to mid 20th centuries such as the University of Nottingham and University of Bristol, plus a few older universities such as the University of Cambridge. Given the importance of these large universities to the UK higher education system it does not seem appropriate to exclude these universities. However, the differences in results presented in Tables 3 and 4 show that the relational influences affecting university centrality in either intra- or inter-regional networks differ, supporting Hypothesis H3.

\section{Conclusion}

This study has sought to understand the factors determining the centrality of universities within networks generated through knowledge flows with industrial and other organisational actors. The study proposes that those universities with the highest rate of centrality within the structure of these networks can be considered to be best representative of the 
type of open innovators that underpin contemporary processes of economic development (Drucker and Goldstein 2007; Howells et al. 2012; Hughes and Kitson 2012). Therefore, it is concluded that the measurement of such centrality represents a novel means of considering the nature of universities as open innovators that adds to and complements existing conceptions. It is found that successful open innovation as measured by network centrality is based on the sustained relational involvement of universities in interactions that foster knowledge exchange, and leads to embedded relationships that promote the opening of additional knowledge flow channels. In other words, openness is engendered as existing relationships mature and become more fruitful, with research-intensive universities being more likely to have the systems and frameworks in place to effectively manage the knowledge flowing through these channels (Enkel et al. 2011; Perkmann et al. 2011a).

Overall, the study finds significant differences in the extent to which universities are capable of acting as centrally-placed networked innovators (confirming Hypothesis 1's suggestion of significant variability), with this capability governed by a number of factors relating to relational involvement (confirming Hypothesis 2). It is initially found that factors relating to the status, prestige, reputation and size of a university determines its positioning within knowledge networks, and thus their open innovation capability. However, these effects are reduced when entrepreneurial and research activities are controlled for, partially confirming Hypothesis 2.4-relating to the role of university status. Engagement in more traditional entrepreneurial activities, such as spinout generation and funded research projects, are found to influence network positioning, although this tends to vary depending on whether all network ties are considered, or just those forming inter-regional networks (partly confirming Hypotheses 2.1 and 2.2).

Importantly, it is those activities associated with higher relational involvement that most positively explain the position of universities in the network, with some evidence that patenting activities may have the opposite effect (this confirms Hypothesis 2.3, but with a negative sign). Potentially, this may reflect the fact that low relational involvement activities involving exclusive arrangements may hinder network development (Argyres and Liebeskind 1998; Nelson 2004). In particular, patent activity has a particularly strong negative association when considering inter-regional networks. This not only confirms the suggestion of Hypothesis 3-that the influence of the forms of relational involvement will differ according to the spatial structure considered-but further hints at the possibility that intellectual property protection may hinder the formation of knowledge-based linkages with significant spatial reach.

Interestingly, locational factors, as measured by regional innovation capability, are found to be largely unrelated to the network centrality of the universities they host (confirming Hypothesis 4). In particular, many universities, especially research-leading institutions, appear to be largely geographically indiscriminate in terms of the actors with which they form networks. From a policy perspective, this suggests that regional policymakers should not blindly pursue the notion that regionally-based knowledge transfer programmes represent a desirable, or even an effective, means for matching the demand for and supply of knowledge for innovation. The study also suggests a range of issues relating to the role of universities in innovation and economic development policies strategies. Clearly, universities need to have access to funds that encourage the type of relations and interactions that develop sustained knowledge networks. Given the focus of many public policy funds on regionally-focused initiatives, the fact that many universities, especially researchleading institutions, are spatially indiscriminate when it comes to network development indicates that future funding policies for innovation should give further consideration to the generation of networks within a more international context. The knowledge residing 
in universities is potentially an asset with global reach, and policymakers and university knowledge transfer offices and programmes should give careful consideration to the provision of the most appropriate mechanisms for ensuring its effective flow.

Nevertheless, from a regional perspective the network analysis indicates a stronger concentration of network ties in leading regions, with network bridging appearing to be significantly stronger in leading regions where cross-cluster connections are more developed. In weaker regions, there is not only a thinness of network connections, but also a lack of depth to connections across firms clustered around particular universities. In general, the analysis make clear that those universities at the centre of networks tend to be leading research-facing institutions with a high propensity for external knowledge-based interaction along with a cohort of highly R\&D-intensive firms.

From a theoretical perspective, the study suggests a greater requirement and scope for integrating the structural nature of the knowledge networks underpinning open innovation. Network structure should be examined in parallel with the spatial nature of these networks, as the spatial reach of network architectures, and the bridging and brokering of ties within and across geographic regions, may be an indicator of the quality and value of the knowledge flowing through these networks. Such knowledge quality and value may also relate to the strength of ties (Huggins and Thompson 2014, 2015), and a more complete analysis should seek to triangulate the three dimensions concerning the structure, spatiality and strength of ties. However, a limitation of this study is that it does not cover tie strength or linkages outside of the UK. Furthermore, its focus on university-industry knowledgebased links presents a partial network structure, which could be complemented by the range of firm-to-firm and university-university links that are likely to exist. Also, the crosssectional nature of the data means that there is limited scope to analyse the evolution and dynamism of network ties. Despite these limitations, however, the analysis suggests a way forward for examining and conceptualising the evolving role of universities as agents of entrepreneurship and innovation within increasingly open economies. The focus of future developments should be on furthering our understanding of the nature of 'openness' in a more holistic sense, and which more broadly encompasses the plethora of interactions and relationships that members of universities engage in. In particular, there are still multiple research gaps concerning a more complete understanding of the flows of knowledge in and out of universities.

Open Access This article is distributed under the terms of the Creative Commons Attribution 4.0 International License (http://creativecommons.org/licenses/by/4.0/), which permits unrestricted use, distribution, and reproduction in any medium, provided you give appropriate credit to the original author(s) and the source, provide a link to the Creative Commons license, and indicate if changes were made.

\section{References}

Aaboen, L., Laage-Hellman, J., Lind, F., Oberg, C., \& Shih, T. (2016). Exploring the roles of university spin-offs in business networks. Industrial Marketing Management, 59, 157-166.

Agrawal, A., Kapur, D., \& McHale, J. (2008). How do spatial and social proximity influence knowledge flows? Evidence from patent data. Journal of Urban Economics, 64(2), 258-269.

Aguiléra, A., Lethiais, V., \& Rallet, A. (2012). Spatial and non-spatial proximities in inter-firm relations: An empirical analysis. Industry and Innovation, 19(3), 187-202.

Ahuja, G. (2000). The duality of collaboration: Inducements and opportunities in the formation of interfirm linkages. Strategic Management Journal, 21, 317-343. 
Andersson, M., \& Karlsson, C. (2007). Knowledge in regional economic growth: The role of knowledge accessibility. Industry and Innovation, 14, 129-149.

Andrade Rojas, M. G., Ramirez Solis, E. R., \& Zhu, J. J. (2018). Innovation and network multiplexity: R\&D and the concurrent effects of two collaboration networks in an emerging economy. Research Policy, 47(6), 1111-1124.

Andrews, D. F., Bickel, P. J., Hampel, F. R., Huber, P. J., Rogers, W. H., \& Tukey, J. W. (1972). Robust estimates of location: Survey and advances. Princeton: Princeton University Press.

Ankrah, S., \& AL-Tabbaa, O. (2015). Universities-industry collaboration: A systematic review. Scandinavian Journal of Management, 31(3), 387-408. https://doi.org/10.1016/j.scaman.2015.02.003.

Argyres, N. S., \& Liebeskind, J. P. (1998). Privatizing the intellectual commons: Universities and the commercialization of biotechnology. Journal of Economic Behavior \& Organization, 35(4), 427-454. https://doi.org/10.1016/S0167-2681(98)00049-3.

Asheim, B., \& Gertler, M. (2005). The geography of innovation: Regional innovation systems. In J. Fagerberg, D. C. Mowery, \& R. R. Nelson (Eds.), The Oxford handbook of innovation (pp. 291-317). Oxford: Oxford University Press.

Athreye, S. (2004). Agglomeration and growth: A study of the Cambridge hi-tech cluster. In T. Bresnahan \& A. Gambardella (Eds.), Building high-tech clusters Silicon Valley and beyond. Cambridge: Cambridge University Press.

Audretsch, D. B., \& Lehmann, E. E. (2006). Entrepreneurial access and absorption of knowledge spillovers: Strategic board and managerial composition for competitive advantage. Journal of Small Business Management, 44(2), 155-166. https://doi.org/10.1111/j.1540-627X.2006.00161.x.

Baglieri, D., Baldi, F., \& Tucci, C. L. (2018). University technology transfer office business models: One size does not fit all. Technovation, 76, 51-63.

Baldini, N. (2006). University patenting and licensing activity: A review of the literature. Research Evaluation, 15(3), 197-207.

Balland, P.-A. (2012). Proximity and the evolution of collaboration networks: Evidence from research and development projects within the Global Navigation Satellite System (GNSS) industry. Regional Studies, 46, 741-756.

Balland, P.-A., Belso-Martínez, J. A., \& Morrison, A. (2016). The dynamics of technical and business knowledge networks in industrial clusters: Embeddedness, status, or proximity? Economic Geography, 92(1), 35-60.

Bathelt, H., \& Glückler, J. (2003). Toward a relational geography. Economic Geography, 3, 117-144.

Bathelt, H., Malmberg, A., \& Maskell, P. (2004). Clusters and knowledge: Local buzz, global pipelines and the process of knowledge creation. Progress in Human Geography, 28, 31-56.

Belussi, F., De Noni, I., \& Orsi, L. (2018). Mapping inventors' networks to trace knowledge flows among EU regions. In A. Isaksen, R. Martin, \& M. Trippl (Eds.), New avenues for regional innovation systems-Theoretical advances, empirical cases and policy lessons (pp. 173-197). Cham: Springer.

Belussi, F., Sammarra, A., \& Sedita, S. R. (2010). Learning at the boundaries in an "Open Regional Innovation System": A focus on firms' innovation strategies in the Emilia Romagna life science industry. Research Policy, 39(6), 710-721.

Benneworth, P., de Boer, H., \& Jongbloed, B. (2015). Between good intentions and urgent stakeholder pressures: Institutionalizing the universities' third mission in the Swedish context. European Journal of Higher Education, 5(3), 280-296.

Berbegal-Mirabent, J., Lafuente, E., \& Solé, F. (2013). The pursuit of knowledge transfer activities: An efficiency analysis of Spanish universities. Journal of Business Research, 66(10), 2051-2059.

Bercovitz, J., \& Feldman, M. (2008). Academic entrepreneurs: Organizational change at the individual level. Organization Science, 19(1), 69-89. https://doi.org/10.1287/orsc.1070.0295.

Bergé, L. R., Wanzenböck, I., \& Scherngell, T. (2017). Centrality of regions in R\&D networks: A new measurement approach using the concept of bridging paths. Regional Studies, 51(8), 1165-1178.

Bergman, E. M. (2009). Embedding network analysis in spatial studies of innovation. Annals of Regional Science, 43(3), 559-565.

Bergman, E. M., \& Maier, G. (2009). Network central: Regional positioning for innovative advantage. Annals of Regional Science, 43(3), 615-644.

Bogers, M., Foss, N. J., \& Lyngsie, J. (2018). The "human side" of open innovation: The role of employee diversity in firm-level openness. Research Policy, 47(1), 218-231.

Bogers, M., Zobel, A.-K., Afuah, A., Almirall, E., Burnswicker, S., Dahlander, L., et al. (2017). The open innovation research landscape: Established perspectives and emerging themes across different levels of analysis. Industry and Innovation, 24(1), 8-40.

Bonaccorsi, A., \& Giuri, P. (2001). Network structure and industrial dynamics: The long-term evolution of the aircraft-engine industry. Structural Change and Economic Dynamics, 12, 201-223. 
Bonarccorsi, A., \& Piccaluga, A. (1994). A theoretical framework for the evaluation of university-industry relationships. R\&D Management, 24(3), 229-247. https://doi.org/10.1111/j.1467-9310.1994.tb008 76.x.

Borgatti, S. P. (2005). Centrality and network flow. Social Networks, 27(1), 55-71.

Boschma, R., Balland, P. A., \& de Vaan, M. (2014). The formation of economic networks: A proximity approach. In A. Torre \& F. Wallet (Eds.), Regional development and proximity relations. Cheltenham: Edward Elgar.

Bouba-Olga, O., Ferru, M., \& Pépin, D. (2012). Exploring spatial features of science-industry partnerships: A study on French data. Papers in Regional Science, 91(2), 355-375.

Bozeman, B., Rimes, H., \& Youtie, J. (2015). The evolving state-of-the-art in technology transfer research: Revisiting the contingent effectiveness model. Research Policy, 44(1), 34-49.

Braunerhjelm, P., Ding, D., \& Thulin, P. (2018). The knowledge spillover theory of intrapreneurship. Small Business Economics, 51(1), 1-30.

Breusch, T. S., \& Pagan, A. R. (1979). A simple test for heteroskedasticity and random coefficient variation. Econometrica, 47(5), 1287-1294.

Broekel, T., Balland, P.-A., \& van Oort, F. (2014). Modeling knowledge networks in economic geography: A discussion of four methods. The Annals of Regional Science, 53(2), 423-452.

Broekel, T., \& Boschma, R. (2012). Knowledge networks in the Dutch aviation industry: The proximity paradox. Journal of Economic Geography, 12(2), 409-433.

Broekel, T., \& Hartog, M. (2013). Explaining the structure of inter-organizational networks using exponential random graph models. Industry and Innovation, 20(3), 277-295.

Burt, R. S. (1982). Toward a structural theory of action: Network models of social structure, perception, and action. New York: Academic.

Burt, R. S. (1992). Structural holes: The social structure of competition. Cambridge, MA: Harvard University Press.

Burt, R. S. (2005). Brokerage and closure: An introduction to social capital. Oxford: Oxford University Press.

Camagni, R. P. (1991). Local 'milieu', uncertainty and innovation networks: Towards a new dynamic theory of space. In R. Camagni (Ed.), Innovation networks. London: Belhaven Press.

Cantner, U., \& Graf, H. (2006). The network of innovation in Jena: An application of social network analysis. Research Policy, 35, 463-480.

Capello, R., \& Camilla, L. (2013). Territorial patterns of innovation and economic growth in European Regions. Growth and Change, 44, 195-227.

Cappellin, R., \& Wink, R. (2009). International knowledge and innovation networks: Knowledge creation and innovation in medium technology clusters. Cheltenham: Edward Elgar.

Carayannis, E. G., \& Meissner, D. (2017). Glocal targeted open innovation: Challenges, opportunities and implications for theory, policy and practice. Journal of Technology Transfer, 42(2), 236-252.

Carlsson, B., \& Fridh, A. C. (2002). Technology transfer in United States universities: A survey and statistical analysis. Journal of Evolutionary Economics, 12(1-2), 199-232.

Cassi, L., \& Plunket, A. (2013). Research collaboration in co-inventor networks: combining closure, bridging and proximities. Regional Studies, (ahead-of-print), 1-19.

Castillo, F., Gilless, J. K., Heiman, A., \& Zilberman, D. (2018). Time of adoption and intensity of technology transfer: An institutional analysis of offices of technology transfer in the United States. Journal of Technology Transfer, 43(1), 120-138.

Cesaroni, F., \& Piccaluga, A. (2016). The activities of university knowledge transfer offices: Towards the third mission in Italy. Journal of Technology Transfer, 41(4), 753-777.

Chang, Y.-C., Yang, P. Y., Martin, B. R., Chi, H.-R., \& Tsai-Lin, T.-F. (2016). Entrepreneurial universities and research ambidexterity: A multilevel analysis. Technovation, 54, 7-21.

Chapple, W., Lockett, A., Siegel, D. S., \& Wright, M. (2005). Assessing the relative performance of UK technology transfer offices: Parametric and non-parametric evidence. Research Policy, 34(3), 369-384.

Chesbrough, H. (2003). Open innovation: The new imperative for creating and profiting from technology. Boston, MA: Harvard Business School Press.

Chesbrough, H. (2011). Open services innovation: Business rethinking your business to grow and compete in a new era. San Francisco, CA: Jossey Bass.

Chesbrough, H., \& Bogers, M. (2014). Explicating open innovation: Clarifying an emerging paradigm for understanding innovation. In H. Chesbrough, W. Vanhaverbeke, \& J. West (Eds.), New frontiers in open innovation (pp. 3-28). Oxford: Oxford University Press.

Chesbrough, H., Vanhaverbeke, W., \& West, J. (Eds.). (2006). Open innovation: Researching a new paradigm. Oxford: Oxford University Press. 
Cohen, J., Cohen, P., West, S. G., \& Aiken, L. S. (2003). Applied multiple regression/correlation analysis for the behavioral sciences. Mahwah, NJ: Lawrence Erlbaum Associates.

Cohen, W. M., \& Levinthal, D. A. (1990). Absorptive capacity: A new perspective on learning and innovation. Administrative Science Quarterly, 35(1), 128-152.

Cohen, W. M., Nelson, R. R., \& Walsh, J. P. (2002). Links and impacts: The influence of public research on industrial R\&D. Management Science, 48(1), 1-23.

Colombo, M. G., D'Adda, D., \& Piva, E. (2010). The contribution of university research to the growth of academic start-ups: An empirical analysis. Journal of Technology Transfer, 35(1), 113-140. https ://doi.org/10.1007/s10961-009-9111-9.

Colombo, M. G., \& Piva, E. (2008). Strengths and weaknesses of academic start-ups: A conceptual model. IEEE Transactions on Engineering Management, 55(1), 37-49. https://doi.org/10.1109/ TEM.2007.912807.

Cooke, P. (2002). Regional innovation systems: General findings and some new evidence from biotechnology clusters. Journal of Technology Transfer, 27(1), 133-145.

Cooke, P., \& Huggins, R. (2003). High-technology clustering in Cambridge. In F. Sforzi (Ed.), The institutions of local development (pp. 51-74). Aldershot: Ashgate.

Crescenzi, R., Filippetti, A., \& Iammarino, S. (2017). Academic inventors: Collaboration and proximity with industry. Journal of Technology Transfer, 42(4), 730-762.

Crescenzi, R., Pietrobelli, C., \& Rabellotti, R. (2013). Innovation drivers, value chains and the geography of multinational corporations in Europe. Journal of Economic Geography. https://doi.org/10.1093/jeg/ lbt01.

D’Ambrosio, A., Gabriele, R., Schavone, F., \& Villasalero, M. (2017). The role of openness in explaining innovation performance in a regional context. Journal of Technology Transfer, 42(2), 389-408.

D'Este, P., Guy, F., \& Iammarino, S. (2013). Shaping the formation of university-industry research collaborations: What type of proximity does really matter? Journal of Economic Geography, 13(4), 537-558.

D'Este, P., \& Iammarino, S. (2010). The spatial profile of university-business research partnerships. Papers in Regional Science, 89(2), 335-351.

D'Este, P., \& Patel, P. (2007). University-industry linkages in the UK: What are the factors underlying the variety of interactions with industry? Research Policy, 36(9), 1295-1313.

D'Este, P., \& Perkmann, M. (2011). Why do academics engage with industry? The entrepreneurial university and individual motivations. Journal of Technology Transfer, 36(3), 316-339. https://doi. org/10.1007/s10961-010-9153-z.

Dahlander, L., \& Gann, D. M. (2010). How open is innovation? Research Policy, 39(6), 699-709.

Davenport, S. (2005). Exploring the role of proximity in SME knowledge-acquisition. Research Policy, 34, $683-701$.

Davids, M., \& Frenken, K. (2018). Proximity, knowledge base and the innovation process: Towards an integrated framework. Regional Studies, 52(1), 23-34.

De Noni, I., Orsi, L., \& Belussi, F. (2018). The role of collaborative networks in supporting the innovation performances of lagging-behind European regions. Research Policy, 47(1), 1-13.

de Nooy, W., Mrvar, A., \& Batagelj, V. (2005). Exploratory social network analysis with pajek. Cambridge: Cambridge University Press.

de Noronha Vaz, T., \& Nijkamp, P. (2009). Knowledge and innovation: The strings between global and local dimensions of sustainable growth. Entrepreneurship and Regional Development, 21(4), 441-455.

de Socio, M. (2010). Marginalization of sunset firms in regime coalitions: A social network analysis. Regional Studies, 44(2), 167-182.

Decter, M., Bennett, D., \& Leseure, M. (2007). University to business technology transfer-UK and USA comparisons. Technovation, 27(5), 145-155.

Di Gregorio, D., \& Shane, S. (2003). Why do some universities generate more start-ups than others? Research Policy, 32(2), 209-227. https://doi.org/10.1016/S0048-7333(02)00097-5.

Di Nauta, P., Merola, B., Caputo, F., \& Evangelista, F. (2018). Reflections on the role of university to face the challenges of knowledge society for the local economic development. Journal of Knowledge Economy, 9(1), 180-198.

Dicken, P., \& Malmberg, A. (2001). Firms in territories: A relational perspective. Economic Geography, 77, 345-363.

Djokovic, D., \& Souitaris, V. (2008). Spinouts from academic institutions: A literature review with suggestions for further research. Journal of Technology Transfer, 33(3), 225-247. https://doi.org/10.1007/ s10961-006-9000-4.

Doloreux, D. (2004). Regional innovation systems in Canada: A comparative study. Regional Studies, 38, 479-492. 
Doloreux, D., \& Dionne, S. (2008). Is regional innovation system development possible in peripheral regions? Some evidence from the case of La Pocatière, Canada. Entrepreneurship and Regional Development, 20, 259-283.

Dong, J. Q., McCarthy, K. J. \& Shoenmakers, W. W. M. E. (2017). How central is too central? Organizing interorganizational collaboration networks for breakthrough innovation. Journal of Product Innovation Management, 34(4), 526-542.

Doran, J., Jordan, D., \& O'Leary, E. (2012). The effects of the frequency of spatially proximate and distant interaction on innovation by Irish SMEs. Entrepreneurship and Regional Development, 24(7-8), 705-727.

Drejer, I., \& Lund Vinding, A. (2007). Searching near and far: Determinants of innovative firms' propensity to collaborate across geographical distance. Industry and Innovation, 14, 259-275.

Drucker, J., \& Goldstein, H. (2007). Assessing the regional economic development impacts of universities: A review of current approaches. International Regional Science Review, 30, 20-46.

Dunning, J. H. (2000). Regions, globalization, and the knowledge economy: The issues stated. In J. H. Dunning (Ed.), Regions, globalization, and the knowledge-based economy (pp. 7-41). Oxford: Oxford University Press.

Enkel, E., Bell, J., \& Hogenkamp, H. (2011). Open innovation maturity framework. International Journal of Innovation Management, 15, 1161-1189.

Etzkowitz, H. (2003). Research groups as 'quasi-firms': The invention of the entrepreneurial university. Research Policy, 32(1), 109-121.

Etzkowitz, H., Webster, A., Gebhardt, C., \& Terra, B. R. C. (2000). The future of the university and the university of the future: Evolution of ivory tower to entrepreneurial paradigm. Research Policy, 29(2), 313-330.

Everett, M., \& Borgatti, S. P. (2005). Ego network betweenness. Social Networks, 27(1), 31-38.

Fantino, D., Mori, A., \& Scalise, D. (2015). Collaboration between firms and universities in Italy: The role of a firm's proximity to top-rated departments. Italian Economic Journal, 1(2), 219-251. https://doi.org/10.1007/s40797-014-0003-2.

Farnstrand Damsgaard, E., \& Thursby, M. C. (2013). University entrepreneurship and professor privilege. Industrial and Corporate Change, 22(1), 183-218.

Feldman, M. P., \& Desrochers, P. (2003). Research universities and local economic development: Lessons from the history of the John Hopkins University. Industry and Innovation, 10(1), 5-24.

Feller, I., Ailes, C., \& Roessner, J. (2002). Impacts of research universities on technological innovation in industry: Evidence from engineering research centers. Research Policy, 31(3), 457-474. https:// doi.org/10.1016/S0048-7333(01)00119-6.

Fini, R., Fu, K., Mathisen, M. T., Rasmussen, E., \& Wright, M. (2017). Institutional determinants of university spin-off quantity and quality: A longitudinal, multilevel, cross-country study. Small Business Economics, 48(2), 361-391.

Fitjar, R. D., \& Rodriguez-Pose, A. (2011). When local interaction does not suffice: Sources of firm innovation in urban Norway. Environment and Planning A, 43, 1248-1267.

Fleming, L., King, C., \& Juda, A. I. (2007). Small worlds and regional innovation. Organization Science, 18, 938-954.

Fleming, L., \& Waguespack, D. M. (2007). Brokerage, boundary spanning, and leadership in open innovation communities. Organization Science, 18(2), 165-180.

Fontes, M. (2005). Distant networking: the knowledge acquisition strategies of 'out-cluster' biotechnology firms. European Planning Studies, 13(6), 899-920.

Freel, M., \& Robson, P. J. (2017). Appropriation strategies and open innovation in SMEs. International Small Business Journal, 35(5), 578-596.

Freeman, L. C. (1977). A set of measures of centrality based on betweenness. Sociometry, 40, 35-40.

Freeman, L. C. (1979). Centrality in social networks: Conceptual clarification. Social Networks, 1(3), 215-239.

Friedman, J., \& Silberman, J. (2003). University technology transfer: Do incentives, management, and location matter? Journal of Technology Transfer, 28(1), 17-30.

Fritsch, M. (2002). Measuring the quality of regional innovation systems: A knowledge production function approach. International Regional Science Review, 25(1), 86-101.

Fritsch, M., \& Slavtchev, V. (2007). Universities and innovation in space. Industry and Innovation, 14, 201-218.

Garnsey, E., \& Heffernan, P. (2005). High-technology clustering through spin-out and attraction: The Cambridge case. Regional Studies, 39, 1127-1144.

Gassmann, O. (2006). Opening up the innovation process: Towards an agenda. R\&D Management, $36(3), 223-228$. 
Gertler, M., \& Levitte, Y. (2005). Local nodes in global networks: The geography of knowledge flows in biotechnology innovation. Industry and Innovation, 13, 487-507.

Gertler, M., \& Wolfe, D. (2004). Ontario's regional innovation system. In P. Cooke, M. Heidenreich, \& H. Braczyk (Eds.), Regional innovation systems: The role of governance in a globalised world (pp. 91-124). London: Routledge.

Glaeser, E. L., Kallal, H. D., Scheinkman, J. A., \& Shleifer, A. (1992). Growth in cities. Journal of Political Economy, 100(6), 1126-1152.

Glückler, J. (2007). Economic geography and the evolution of networks. Journal of Economic Geography, 7, 619-634.

Gulati, R., Sytch, M., \& Tatarynowicz, A. (2012). The rise and fall of small worlds: Exploring the dynamics of social structure. Organization Science, 23(2), 449-471.

Gulbrandsen, M., \& Slipersæter, S. (2007). The third mission and the entrepreneurial university model. In A. Bonaccorsi \& C. Daraio (Eds.), Universities and strategic knowledge creation: Specialization and performance in Europe (pp. 112-143). Cheltenham: Edward Elgar.

Haeussler, C., \& Colyvas, J. A. (2011). Breaking the ivory tower: Academic entrepreneurship in the life sciences in UK and Germany. Research Policy, 40(1), 41-54. https://doi.org/10.1016/j.respo 1.2010.09.012.

Herstad, S. J., \& Ebersberger, B. (2015). On the link between urban location and the involvement of knowledge-intensive business services firms in collaboration networks. Regional Studies, 49(7), 1160-1175.

Hewitt-Dundas, N. (2012). Research intensity and knowledge transfer activity in UK universities. Research Policy, 41(2), 262-275.

Hewitt-Dundas, N. (2013). The role of proximity in university-business cooperation for innovation. Journal of Technology Transfer, 38(2), 93-115.

Hollanders, H., Es-Sadki, N., Buligescu, B., Rivera Leon, L., Griniece, E., \& Roman, L. (2014). Regional innovation scoreboard 2014. Brussels: European Commission.

Howells, J. (2005). Innovation and regional economic development: A matter of perspective? Research Policy, 34(8), 1220-1234.

Howells, J., Nevada, M., \& Georghiou, L. (1998). Industry-academic links in the UK: A report to the higher education funding councils of England, Scotland and Wales, PREST. Manchester: University of Manchester.

Howells, J., Ramlogan, R., \& Cheng, S. (2012). Innovation and university collaboration: Paradox and complexity within the knowledge economy. Cambridge Journal of Economics, 36(3), 703-721.

Huber, F. (2012a). Do clusters really matter for innovation practices in Information Technology? Questioning the significance of technological knowledge spillovers. Journal of Economic Geography, 12, 107-126.

Huber, F. (2012b). On the role and interrelationship of spatial, social and cognitive proximity: Personal knowledge relationships of R\&D workers in the Cambridge information technology cluster. Regional Studies, 46(9), 1169-1182.

Huggins, R. (2003). Creating a UK competitiveness index: regional and local benchmarking'. Regional Studies, 37(1), 89-96.

Huggins, R., \& Izushi, H. (2007). Competing for knowledge: Creating, connecting and growing. London: Routledge.

Huggins, R., \& Johnston, A. (2009). Knowledge networks in an uncompetitive region: SME innovation and growth. Growth and Change, 40(2), 227-259.

Huggins, R., Johnston, A., \& Steffenson, R. (2008). Universities, knowledge networks and regional policy. Cambridge Journal of Regions, Economy and Society, 2(1), 321-340.

Huggins, R., Johnston, A., \& Stride, C. (2012a). Knowledge networks and universities: Locational and organisational aspects of knowledge transfer interactions. Entrepreneurship and Regional Development, 24(7-8), 475-502.

Huggins, R., \& Kitagawa, F. (2012). Regional policy and university knowledge transfer: Perspectives from devolved regions in the UK. Regional Studies, 46(6), 817-832.

Huggins, R., \& Prokop, D. (2017). Network structure and regional innovation: A study of university-industry ties. Urban Studies, 54(4), 931-952.

Huggins, R., \& Thompson, P. (2014). A network-based view of regional growth. Journal of Economic Geography, 14(3), 511-545.

Huggins, R., \& Thompson, P. (2013). Competitiveness and the post-regional political economy. Local Economy, 28(7/8), 884-893.

Huggins, R., \& Thompson, P. (2015). Entrepreneurship, innovation and regional growth: A network theory. Small Business Economics, 45(1), 103-128.

Huggins, R., \& Thompson, P. (2017). Networks and regional economic growth: a spatial analysis of knowledge ties. Environment and Planning A, 49(6), 1247-1265. 
Huggins, R., Thompson, P., \& Johnston, A. (2012b). Network capital, social capital, and knowledge flow: How the nature of inter-organisational networks impacts on innovation. Industry and Innovation, 19(3), 203-232.

Hughes, A., \& Kitson, M. (2012). Pathways to impact and the strategic role of universities: New evidence on the breadth and depth of university knowledge exchange in the UK and the factors constraining its development. Cambridge Journal of Economics, 36(3), 723-750.

Hunter, D. R., Goodreau, S. M., \& Handcock, M. S. (2008). Goodness of fit of social network models. Journal of the American Statistical Association, 103(481), 248-258.

Izushi, H. (1997). Conflict between two industrial networks: Technological adaptation and interfirm relationships in the ceramics industry in Seto, Japan. Regional Studies, 31, 117-129.

Jefferson, D. J., Maida, M., Farkas, A., Alandete-Saez, M., \& Bennett, A. B. (2017). Technology transfer in the Americas: Common and divergent practices among major research universities and public sector institutions. Journal of Technology Transfer, 42(6), 1307-1333.

Johnston, A., \& Huggins, R. (2016). Drivers of university-industry links: The case of knowledge-intensive business service firms in rural locations. Regional Studies, 50(8), 1330-1345.

Johnston, A., \& Huggins, R. (2017). University-industry links and the determinants of their spatial scope: A study of the knowledge intensive business services sector. Papers in Regional Science, 96(2), 247-260.

Jonsson, L., Baraldi, E., Larsson, L. E., Forsberg, P., \& Severinsson, K. (2015). Targeting academic engagement in open innovation: Tools, effects and challenges for university management. Journal of the Knowledge Economy, 6(3), 522-550.

Kim, T., Park, K., \& Kim, E. (2018). Complementary or contradictory? The effects of structural holes and status on innovation. Innovation. https://doi.org/10.1080/14479338.2018.1478733.

Knoben, J., Gilsing, V. A., \& Krijkamp, A. R. (in press). From homophily through embeddedness to strategy: The role of network accuracy in partner selection choices. Long Range Planning. https://doi. org/10.1016/j.lrp.2018.06.001.

Knoben, J., \& Oerlemans, L. A. G. (2012). Configurations of inter-organizational knowledge links: Does spatial embeddedness still matter? Regional Studies, 46(8), 1005-1021.

Knoben, J., Oerlemans, L. A. G., \& Rutten, R. P. J. H. (2006). Radical changes in inter-organizational network structures: The longitudinal gap. Technological Forecasting and Social Change, 73(4), 390-404.

Knoke, D., \& Kuklinski, J. (1982). Network analysis. Beverley Hills, CA: Sage.

Krätke, S. (2010). Regional knowledge networks: A network analysis approach to the interlinking of knowledge resources. European Urban and Regional Studies, 17, 83-97.

Lambert, R. (2003). Lambert review of business-university collaboration. Norwich: HMSO.

Latorre, M. P., Hermoso, R., \& Rubio, M. A. (2017). A novel network-based analysis to measure efficiency in science and technology parks: The ISA framework approach. The Journal of Technology Transfer, 42(6), 1255-1275.

Laursen, K., Reichstein, T., \& Salter, A. (2011). Exploring the effect of geographical proximity and university quality on university-industry collaboration in the United Kingdom. Regional Studies, 45(4), 507-523.

Laursen, K., \& Salter, A. (2006). Open for innovation: The role of openness in explaining innovation performance among U.K. manufacturing firms. Strategic Management Journal, 27(2), 131-150.

Laursen, K., \& Salter, A. J. (2014). The paradox of openness: Appropriability, external search and collaboration. Research Policy, 43(5), 867-878.

Lawton Smith, H. (2003). Knowledge organizations and local economic development: The cases of Oxford and Grenoble. Regional Studies, 37(9), 899-919.

Lawton Smith, H. (2007). Universities, innovation, and territorial development: A review of the evidence. Environment and Planning C: Government and Policy, 25, 98-114.

Lawton Smith, H., \& Bagchi-Sen, S. (2006). University-industry interactions: The case of the UK biotech industry. Industry and Innovation, 13(4), 371-392.

Lawton Smith, H., Chapman, D., Wood, P., Barnes, T., \& Romeo, S. (2014). Entrepreneurial academics and regional innovation systems: The case of spin-offs from London's universities. Environment and Planning C: Government and Policy, 32(2), 341-359.

Lee, Y. S. (2000). The sustainability of university-industry research collaboration: An empirical assessment. Journal of Technology Transfer, 25(2), 111-133.

Lee, C., Lee, K., \& Pennings, J. M. (2001). Internal capabilities, external networks, and performance: A study on technology-based ventures. Strategic Management Journal, 22(6-7), 615-640.

Leon, R.-D., Rodríguez-Rodríguez, R., Gómez-Gasquet, P., \& Mula, J. (2017). Social network analysis: A tool for evaluating and predicting future knowledge flows from an insurance organization. Technological Forecasting and Social Change, 114, 103-118. 
Liang, X., \& Liu, A. M. M. (2018). The evolution of government sponsored collaboration network and its impact on innovation: A bibliometric analysis in the Chinese solar PV sector. Research Policy, 47(7), 1295-1308.

Liang, K.-Y., \& Zeger, S. L. (1986). Longitudinal data analysis using generalized linear models. Biometrika, $73(1), 13-22$.

Lissoni, F. (2001). Knowledge codification and the geography of innovation: The case of Brescia mechanical cluster. Research Policy, 30, 1479-1500.

Lockett, A., \& Wright, M. (2005). Resources, capabilities, risk capital and the creation of university spinout companies. Research Policy, 34(7), 1043-1057. https://doi.org/10.1016/j.respol.2005.05.006.

Lockett, A., Wright, M., \& Franklin, S. (2003). Technology transfer and universities' spin-out strategies. Small Business Economics, 20(2), 185-201.

López-Martínez, R. E., Medellín, E., Scanlon, A. P., \& Solleiro, J. L. (1994). Motivations and obstacles to university industry cooperation (UIC): A Mexican case. R\&D Management, 24(1), 017-030. https:// doi.org/10.1111/j.1467-9310.1994.tb00844.x.

Lorentzen, A. (2008). Knowledge networks in local and global space. Entrepreneurship and Regional Development, 20, 533-545.

Lundvall, B.-A. (Ed.). (1992). National systems of innovation. London: Pinter.

Lyu, Y., Liu, Q., He, B., \& Nie, J. (2017). Structural embeddedness and innovation diffusion: The moderating role of industrial technology grouping. Scientometrics, 111, 889-916.

Maggioni, M., \& Uberti, T. E. (2009). Knowledge networks across Europe: Which distance matters? Annals of Regional Science, 43, 691-720.

Maggioni, M., \& Uberti, E. (2011). Networks and geography in the economics of knowledge flows. Quality \& Quantity, 45, 1031-1051.

Martinus, K. and Sigler, T. J. (2017). Global city clusters: Theorizing spatial proximity in inter-urban firm networks. Regional Studies, https://doi.org/10.1080/00343404.2017.1314457.

Massard, N., \& Mehier, C. (2009). Proximity and innovation through an 'accessibility to knowledge'lens. Regional Studies, 43(1), 77-88.

Mattes, J. (2012). Dimensions of proximity and knowledge bases: Innovation between spatial and nonspatial factors. Regional Studies, 46(8), 1085-1099.

McEvily, B., \& Zaheer, A. (1999). Bridging ties: A source of firm heterogeneity in competitive capabilities. Strategic Management Journal, 20, 1133-1156.

Mejlgaard, N., \& Ryan, T. K. (2017). Patterns of third mission engagement among scientists and engineers. Research Evaluation, 26(4), 326-336.

Mitchell, J. C. (1969). The concept and use of social networks. In J. C. Mitchell (Ed.), Social networks in urban situations. Manchester: Manchester University Press.

Murray, F. (2004). The role of academic investors in entrepreneurial firms: Sharing the laboratory life. Research Policy, 33(4), 643-659. https://doi.org/10.1016/j.respol.2004.01.013.

Nelson, R. R. (2004). The market economy, and the scientific commons. Research Policy, 33(3), 455471. https://doi.org/10.1016/j.respol.2003.09.008.

Newberg, J. A., \& Dunn, R. L. (2002). Keeping secrets in the campus lab: Law, values and rules of engagement for industry-university R\&D partnerships. American Business Law Journal, 39(2), 187-241. https://doi.org/10.1111/j.1744-1714.2002.tb00298.x.

NSF. (2006). Science and technology indicators. Arlington, VA: National Science Foundation.

O'Kane, C., Mangematin, V., Geoghegan, W., \& Fitzgerald, C. (2015). University technology transfer offices: The search for identity to build legitimacy. Research Policy, 44(2), 421-437.

O'Reilly, P., \& Cunningham, J. A. (2017). Enablers and barriers to university technology transfer engagements with small- and medium-sized enterprises: Perspectives of principal investigators. Small Enterprise Research, 24(3), 274-289.

O’Shea, R. P., Allen, T. J., Chevalier, A., \& Roche, F. (2005). Entrepreneurial orientation, technology transfer and spinoff performance of US universities. Research Policy, 34(7), 994-1009. https://doi. org/10.1016/j.respol.2005.05.011.

Owen-Smith, J., \& Powell, W. W. (2004). Knowledge networks as channels and conduits: The effects of spillovers in the Boston biotechnology community. Organizational Science, 15, 5-21.

Palazzo, G. (2005). Postnational constellations of innovativeness: A cosmopolitan approach. Technology Analysis \& Strategic Management, 17, 55-72.

Pan, F., Bi, W., Liu, X. \& Sigler, T. (2018). Exploring financial centre networks through inter-urban collaboration in high-end financial transactions in China. Regional Studies. https://doi.org/10.1080/00343 404.2018.1475728. 
Park, T.-Y., Lim, H. \& Ji, I. (2018). Identifying potential users of technology for technology transfer using patent citation analysis: A case analysis of a Korean research institute. Scientometrics, 116, 1541-1558.

Pérez Pérez, M., \& Martínez Sánchez, A. (2003). The development of university spin-offs: Early dynamics of technology transfer and networking. Technovation, 23(10), 823-831.

Perkmann, M., King, Z., \& Pavelin, S. (2011a). Engaging excellence? Effects of faculty quality on university engagement with industry. Research Policy, 40(4), 539-552. https://doi.org/10.1016/j. respol.2011.01.007.

Perkmann, M., Neely, A., \& Walsh, K. (2011b). How should firms evaluate success in university-industry alliances? A performance measurement system. R\&D Management, 41, 202-216.

Perkmann, M., Tartari, V., McKelvey, M., Autio, E., Broström, A., D’Este, P., et al. (2013). Academic engagement and commercialisation: A review of the literature on university-industry relations. Research Policy, 42(2), 423-442. https://doi.org/10.1016/j.respol.2012.09.007.

Perkmann, M., \& Walsh, K. (2007). University-industry relationships and open innovation: Towards a research agenda. International Journal of Management Reviews, 9(4), 259-280.

Phan, P. H., Siegel, D. S., \& Wright, M. (2005). Science parks and incubators: Observations, synthesis and future research. Journal of Business Venturing, 20(2), 165-182.

Polenske, K. (Ed.). (2007). The economic geography of innovation. Cambridge: Cambridge University Press.

Ponds, R., van Oort, F., \& Frenken, K. (2007). The geographical and institutional proximity of research collaboration. Papers in Regional Science, 86(3), 423-443.

Ponds, R., van Oort, F., \& Frenken, K. (2010). Innovation, spillovers and university-industry collaboration: An extended knowledge production function approach. Journal of Economic Geography, $10(2), 231-255$.

Ponomariov, V. (2008). Effects of university characteristics on scientists' interactions with the private sector: An exploratory assessment. Journal of Technology Transfer, 33(5), 485-503. https://doi. org/10.1007/s10961-007-9047-x.

Ponomariov, V., \& Boardman, P. C. (2008). The effect of informal industry contacts on the time university sciences allocation to collaborative research with industry. Journal of Technology Transfer, 33(3), 301-313. https://doi.org/10.1007/s10961-007-9029-z.

Powell, W. W., Koput, K. W., \& Smith-Doerr, L. (1996). Interorganizational collaboration and the locus of innovation: Networks of learning in biotechnology. Administrative Science Quarterly, 41, 116-145.

Protogerou, A., Caloghirou, Y., \& Siokas, E. (2013). Twenty-five years of science-industry collaboration: The emergence and evolution of policy-driven research networks across Europe. The Journal of Technology Transfer, 38(6), 873-895.

Qiu, S., Liu, X., \& Gao, T. (2017). Do emerging countries prefer local knowledge or distant knowledge? Spillover effect of university collaborations on local firms. Research Policy, 46(7), 1299-1311.

Reynolds, E. B., \& Uygun, Y. (2018). Strengthening advanced manufacturing innovation ecosystems: The case of Massachusetts. Technological Forecasting and Social Change, 136, 178-191. https://doi. org/10.1016/j.techfore.2017.06.003.

Roberts, E. B. (1991). High tech entrepreneurs: Lessons from MIT and beyond. New York: Oxford University Press.

Roper, S., \& Love, J. H. (2018). Knowledge context, learning and innovation: An integrating framework. Industry and Innovation, 25(4), 339-364.

Rosa, J. M., \& Mohnen, P. (2007). Knowledge transfers between Canadian business enterprises and universities: Does distance matter? Annales d'Économie et de Statistique, 87(88), 303-323.

Rosli, A., \& Rossi, F. (2016). Third-mission policy goals and incentives from performance-based funding: Are they aligned? Research Evaluation, 25(4), 427-441.

Ryu, W., McCann, B. T., \& Reuer, J. J. (2018). Geographic co-location of partners and rivals: Implications for the design of R\&D Alliances. Academy of Management Journal, 61(3), 945-965.

Sainsbury, D. (2007). The race to the top: A review of government's science and innovation policies. London: HMSO.

Santoro, M. D., \& Chakrabarti, A. K. (2002). Firm size and technology centrality in industry-university interactions. Research Policy, 31, 1163-1180.

Santoro, G., Ferraris, A., Giacosa, E., \& Giovando, G. (2018). How SMEs engage in open innovation: a survey. Journal of the Knowledge Economy, 9(2), 561-574.

Santoro, M. D., \& Gopalakrishnan, S. (2001). Relationship dynamics between university research centers and industrial firms: Their impact on technology transfer activities. Journal of Technology Transfer, 26(1), 163-174. https://doi.org/10.1023/A:1007804816426. 
Saxenian, A. (1994). Regional advantage: Culture and competition in silicon valley and route 128. Cambridge, MA: Harvard University Press.

Saxenian, A. (2005). From brain drain to brain circulation: Transnational communities and regional upgrading in India and China. Studies in Comparative International Development, 40, 35-61.

Schaeffer, V., Öcalan-Özel, S., \& Pénin, J. (2018). The complementarities between formal and informal channels of university-industry knowledge transfer: A longitudinal approach. Journal of Technology Transfer. https://doi.org/10.1007/s10961-018-9674-4.

Schartinger, D., Rammer, C., Fischer, M. M., \& Fröhlich, J. (2002). Knowledge interactions between universities and industry in Austria: Sectoral patterns and determinants. Research Policy, 31(3), 303-328. https://doi.org/10.1016/S0048-7333(01)00111-1.

Schartinger, D., Schibany, A., \& Gassler, H. (2001). Interactive relations between universities and firms: Empirical evidence for Austria. Journal of Technology Transfer, 26(3), 255-268. https://doi. org/10.1023/A:1011110207885.

Schilling, M. A., \& Phelps, C. C. (2007). Interfirm collaboration networks: The impact of large-scale network structure on firm innovation. Management Science, 53(7), 1113-1126.

Scott, J. (2000). Social network analysis: A handbook (2nd ed.). London: Sage.

Sebestyén, T., \& Varga, A. (2013). Research productivity and the quality of interregional knowledge networks. Annals of Regional Science, 51(1), 155-189.

Sengupta, A., \& Ray, A. S. (2017). University research and knowledge transfer: A dynamic view of ambidexterity in British universities. Research Policy, 46(5), 881-897.

Shane, S., \& Cable, D. (2002). Network ties, reputation, and the financing of new ventures. Management Science, 48(3), 364-381.

Sharifi, H., Liu, W., \& Ismail, H. S. (2014). Higher education system and the 'open'knowledge transfer: A view from perception of senior managers at university knowledge transfer offices. Studies in Higher Education, 39(10), 1860-1884.

Siegel, D. S., Waldman, D., \& Link, A. (2003). Assessing the impact of organizational practices of the relative productivity of university technology transfer offices: An exploratory study. Research Policy, 32(1), 27-48.

Simard, C., \& West, J. (2006). Knowledge networks and the geographic locus of innovation. In H. Chesbrough, W. Vanhaverbeke, \& J. West (Eds.), Open innovation: Researching a new paradigm (pp. 220-240). Oxford: Oxford University Press.

Soete, L. (1999). The challenges and the potential of the knowledge-based economy in a globalised world in João. In M. Rodrigues (Ed.), The new knowledge economy in Europe: A strategy for international competitiveness and social cohesion (pp. 28-53). Cheltenham: Edward Elgar.

Sonmez, Z. (2018). Interregional inventor collaboration and the commercial value of patented inventions: Evidence from the US biotechnology industry. The Annals of Regional Science. https://doi. org/10.1007/s00168-018-0874-5.

Sorenson, O., Rivkin, J. W., \& Fleming, L. (2006). Complexity, networks and knowledge flow. Research Policy, 35, 994-1017.

Stanko, M. A., Fisher, G. J., \& Bogers, M. (2017). Under the wide umbrella of open innovation. Journal of Product Innovation Management, 34(4), 543-558.

Stuart, T. E. (1998). Network positions and propensities to collaborate: An investigation of strategic alliance formation in a high-technology industry. Administrative Science Quarterly, 43(3), 668-698.

Stuart, T. E., \& Ding, W. W. (2006). When do scientists become entrepreneurs? The social structure of antecedents of commercial activity in the academic life sciences. American Journal of Sociology, 112(1), 97-144.

Stuart, T. E., Ozdemir, S. Z., \& Ding, W. W. (2007). Vertical alliance networks: The case of university-biotechnology-pharmaceutical alliance chains. Research Policy, 36(4), 477-498. https://doi. org/10.1016/j.respol.2007.02.016.

Sturgeon, T. (2003). What really goes on in Silicon Valley? Spatial clustering and dispersal in modular production networks. Journal of Economic Geography, 3(2), 199-225.

Sun, Y. \& Cao, C. (2018). The evolving relations between government agencies of innovation policymaking in emerging economies: A policy network approach and its application to the Chinese case. Research Policy, 47, 592-605.

Szücs, F. (2018). Research subsidies, industry-university cooperation and innovation. Research Policy, 47(7), 1256-1266.

Tang, C., Zhang, G., \& Naumann, S. E. (2017). When do structural holes in employees' networks improve their radical creativity? A moderated mediation model. R\&D Management, 47(5), 755-766. 
Teixeira, A., Santos, P., \& Oliveira Brochado, A. (2006). Does proximity really matter in international $R \& D$ cooperative projects?, Paper presented at the European Network on Industrial Policy (EUNIP) 9th international conference, June 20-22, in Limerick, Ireland.

Ter Wal, A. L. J., \& Boschma, R. A. (2009). Applying social network analysis in economic geography: Framing some key analytic issues. Annals of Regional Science, 43, 739-756.

Ter Wal, A. L. J., \& Boschma, R. (2011). Co-evolution of firms, industries and networks in space. Regional Studies, 45, 919-933.

Tödtling, F., \& Trippl, M. (2005). One size fits all? Towards a differential regional innovation policy approach. Research Policy, 34(8), 1203-1219.

Torré, A. (2008). On the role played by temporary geographical proximity in knowledge transmission. Regional Studies, 42(6), 869-889.

Tortoriello, M. (2015). The social underpinnings of absorptive capacity: The moderating effects of structural holes on innovation generation based on external knowledge. Strategic Management Journal, 36(4), 586-597.

Trippl, M., Grillitsch, M., \& Isaksen, A. (2017). Exogenous sources of regional industrial change: Attraction and absorption of non-local knowledge for new path development. Progress in Human Geography, 1, 1-19.

Vallance, P., Blažek, J., Edwards, J., \& Květoň, V. (2018). Smart specialisation in regions with lessdeveloped research and innovation systems: A changing role for universities? Environment and Planning C: Politics and Space, 36(2), 219-238.

van Geenhuizen, M. (2008). Knowledge networks of young innovators in the urban economy: Biotechnology as a case study. Entrepreneurship and Regional Development, 20(2), 161-183.

Van Looy, B., Landoni, P., Callaert, J., van Pottlesberghe, B., Sapsalis, E., \& Dabackere, K. (2011). Entrepreneurial effectiveness of European universities: An empirical assessment of antecedents and trade-offs. Research Policy, 40(4), 553-564.

Varga, A., \& Parag, A. (2009). Academic knowledge transfers and the structure of international research networks. In A. Varga (Ed.), Universities, knowledge transfer and regional development: Geography, entrepreneurship and policy. Cheltenham: Edward Elgar.

Verspagen, B. (2006). University research, intellectual property rights and European innovation systems. Journal of Economic Surveys, 20(4), 607-632.

Vonortas, N. S. (2009). Innovation networks in industry. In F. Malerba \& N. S. Vonortas (Eds.), Innovation networks in industry. Cheltenham: Edward Elgar.

Wasserman, S., \& Faust, K. (1994). Social network analysis: Methods and applications. Cambridge: Cambridge University Press.

Watts, D. J. (1999). Small worlds: The dynamics of networks between order and randomness. Priceton: Princeton University Press.

Wellings, P. (2008). Intellectual property and research benefits. Lancaster: Lancaster University.

White, H. (1980). A heteroskedasticity-consistent covariance matrix estimator and a direct test for heteroscedasticity. Econometrica, 48(4), 817-838.

Whittington, K. B., Owen-Smith, J., \& Powell, W. W. (2009). Networks, propinquity, and innovation in knowledge-intensive industries. Administrative Science Quarterly, 54, 90-122.

Wolfe, D., \& Gertler, M. (2004). Clusters from the inside and out: Local dynamics and global linkages. Urban Studies, 41, 1071-1093.

Wright, M., Lockett, A., Clarysse, B., \& Binks, M. (2006). University spin-out companies and venture capital. Research Policy, 35(4), 481-501.

Zaheer, A., \& Bell, G. (2005). Benefiting from network position: Firm capabilities, structural holes, and performance. Strategic Management Journal, 26, 809-825.

Zaheer, A., Gözübüyük, R., \& Milanov, H. (2010). It's the connections: The network perspective in interorganizational research. Academy of Management Perspectives, 24(1), 62-77.

Zaheer, A., \& Soda, G. (2009). Network evolution: The origins of structural holes. Administrative Science Quarterly, 54, 1-31.

Zang, J. (2018). Structural holes, exploratory innovation and exploitative innovation. Management Decision, $56(8), 1682-1695$.

Zucker, L., Darby, M., \& Brewer, M. (1998). Intellectual human capital and the birth of US biotechnology enterprises. American Economic Review, 88(1), 290-305.

Publisher's Note Springer Nature remains neutral with regard to jurisdictional claims in published maps and institutional affiliations. 